\title{
Insect herbivory and herbivores of Ficus species along a rainforest elevational gradient in Papua New Guinea
}

by Sam, K., Koane, B., Sam, L., Mrazova, A., Segar, S., Volf, M., Moos, M., Simek, P., Sisol, M. and Novotny, V.

Copyright, publisher and additional information: this is the author accepted manuscript. The final published version (version of record) is available online via Wiley. This article may be used for non-commercial purposes in accordance with Wiley Terms and Conditions for Self-Archiving.

Please refer to any applicable terms of use of the publisher.

DOI: https://doi.org/10.1111/btp.12741

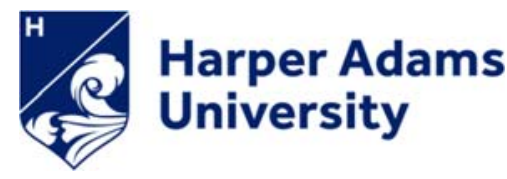

Sam, K., Koane, B., Sam, L., Mrazova, A., Segar, S., Volf, M., Moos, M., Simek, P., Sisol, M. and Novotny, V. 2020. Insect herbivory and herbivores of Ficus species along a rainforest elevational gradient in Papua New Guinea. BioTropica. 


\section{Insect herbivory and herbivores of Ficus species along a rainforest elevational gradient in Papua New Guinea}

\begin{tabular}{|c|c|}
\hline Journal: & Biotropica \\
\hline Manuscript ID & BITR-18-340.R1 \\
\hline Manuscript Type: & Paper \\
\hline $\begin{array}{r}\text { Date Submitted by the } \\
\text { Author: }\end{array}$ & 19-Aug-2019 \\
\hline Complete List of Authors: & $\begin{array}{l}\text { Sam, Katerina; Biology Centre CAS, Institute of Entomology; University } \\
\text { of South Bohemia, Faculty of Sciences } \\
\text { Koane, Bonny; The New Guinea Binatang Research Centre } \\
\text { Sam, Legi; Biology Centre CAS, Institute of Entomology } \\
\text { Mrazova, Anna; Biology Centre CAS, Institute of Entomology; University } \\
\text { of South Bohemia, Faculty of Sciences } \\
\text { Segar, Simon; Biology Centre of Czech Academy of Sciences, Institute of } \\
\text { Entomology Branisovska } 31 \text { Ceske Budejovice, CZ 37005, Tropical } \\
\text { Ecology; University of South Bohemia, Faculty of Sciences; Harper } \\
\text { Adams University, Department of Crop and Environment Sciences } \\
\text { Volf, Martin; Biology Centre CAS, Institute of Entomology; University of } \\
\text { South Bohemia, Faculty of Sciences; German Centre for Integrative } \\
\text { Biodiversity Research (iDiv) Halle-Jena-Leipzig } \\
\text { Moos, Martin; Biology Centre CAS, Institute of Entomology } \\
\text { Simek, Petr; Biology Centre CAS, Institute of Entomology } \\
\text { Sisol, Mentap; The New Guinea Binatang Research Centre } \\
\text { Novotny, Vojtech; Institute of Entomology; University of South Bohemia, } \\
\text { Faculty of Sciences }\end{array}$ \\
\hline Keywords: & $\begin{array}{l}\text { leaf damage, leaf chewers, defensive traits, defoliating insect, } \\
\text { phytophagy, plant-herbivore interactions, trophic interactions, altitudinal } \\
\text { gradient, bottom-up interactions }\end{array}$ \\
\hline
\end{tabular}

\section{SCHOLARONE Manuscripts}




\title{
Insect herbivory and herbivores of Ficus species along a rainforest elevational gradient in Papua New Guinea
}

\author{
Running title: Herbivory along elevation

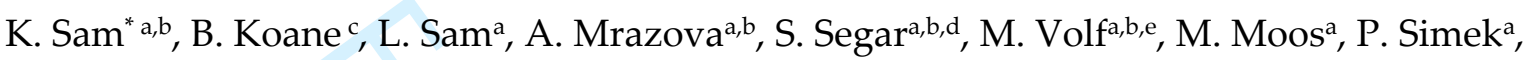 \\ M. Sisolc, V. Novotny ${ }^{\mathrm{a}, \mathrm{b}}$
}

a Biology Centre of Czech Academy of Sciences, Institute of Entomology, Ceske Budejovice, Czech Republic

b Faculty of Science, University of South Bohemia, Ceske Budejovice, Czech Republic

c The New Guinea Binatang Research Center, Madang, Papua New Guinea

${ }^{\mathrm{d}}$ Department of Crop and Environment Sciences, Harper Adams University, UK

e Molecular Interaction Ecology Group, German Centre for Integrative Biodiversity Research (iDiv) Halle-Jena-Leipzig, Leipzig, Germany

*Corresponding author Katerina Sam: katerina.sam.cz@gmail.com

Orcid ID of Katerina Sam: orcid.org/0000-0002-3436-0579

Associate Editor: Emilio Bruna; Handling Editor: Roger Kitching

Received 23 December 2018; revisions accepted 12 November 2019. 


\section{Abstract}

Classic research on elevational gradients in plant-herbivore interactions holds that insect herbivore pressure is stronger under warmer climates of low elevations. However, recent work has questioned this paradigm, arguing that it oversimplifies the ecological complexity in which plant-insect herbivore interactions are embedded. Knowledge of antagonistic networks of plants and herbivores is however crucial for understanding the mechanisms that govern ecosystem functioning. We examined herbivore damage and insect herbivores of eight species of genus Ficus (105 saplings) and plant constitutive defensive traits of two of these species, along a rainforest elevational gradient of Mt. Wilhelm (200 - $2700 \mathrm{~m}$ a.s.1.), in tropical Papua New Guinea. We report overall herbivore damage 2.4\% of leaf area, ranging from $0.03 \%$ in Ficus endochaete at $1700 \mathrm{~m}$ a.s.1. to $6.1 \%$ in F. hombroniana at $700 \mathrm{~m}$ a.s.1.

Herbivore damage and herbivore abundances varied significantly with elevation, as well as among the tree species, and between the wet and dry season. Community-wide herbivore damage followed a hump-shaped pattern with the peak between 700 and $1200 \mathrm{~m}$ a.s.l. and this pattern corresponded with abundance of herbivores. For two tree species surveyed in detail, we observed decreasing and hump-shaped patterns in herbivory, in general matching the trends found in the set of plant defences measured here. Our results imply that vegetation growing at mid-elevations of the elevational gradient, i.e. at the climatically most favourable elevations where water is abundant, and temperatures still relatively warm, suffers the maximum amount of herbivorous damage which changes seasonally, reflecting the water availability. 
Key-words leaf damage, leaf-chewers, defensive traits, defoliating insects, phytophagy, plant-herbivore interactions, trophic interactions, altitudinal gradient, top-down interactions. 


\section{Introduction}

Arthropods are a major component of ecosystems, in terms of both their biomass and the variety of functional roles they play. Insect herbivores, as the most important primary consumers in tropical forests, consume up to $\sim 70 \%$ of total leaf area (Coley \& Barone 1996). In tropical Asia, insect herbivory accounted for over $98 \%$ of the leaf loss, and $93 \%$ of the insect herbivory was due to chewing insects alone (Adams et al. 2009). Other studies report that, on average, insect herbivores consume 18 percent of the biomass produced annually in terrestrial ecosystems (Cyr \& Face 1993), and these losses roughly correspond to the energy invested by plants into reproduction (Schoonhoven et al. 2005). The relationships between plants and herbivores are therefore among the most intensively studied biotic interactions (Moles et al. 2011a, Moles et al. 2011b, Jamieson et al. 2012, Kozlov et al. 2015, Anstett et al. 2016). Yet we lack a clear understanding of how arthropod abundances change along environmental gradients and what functions they play along them.

Due to arthropod's enormous diversity, it is difficult to examine patterns of species richness across all arthropods and most studies tend to focus on one (e.g. Niemela et al. 1992, Brehm et al. 2003, Sanders et al. 2007) or several taxonomic groups (e.g. Peters et al. 2016), rather than on whole feeding guilds or on patterns of total arthropod abundances.

There is a general assumption in the literature that herbivory (more exactly, folivory, because plant damage by sap-feeders and root-feeders is usually not considered) decreases with increasing elevation. Hypothesised mechanism for this pattern include greater diversity of herbivores (e.g. Hodkinson 2005, Beck et al. 2011), more specialist consumers (Rodríguez-Castañeda et al. 2010) and their higher consumption per capita (Scheidel \& Bruelheide 2001) at lower elevations; elevational difference in host-plant quality (Hodkinson 2005) and reduced abundances of insects at higher elevations owing to lower temperatures 
(Hodkinson 2005). The relative costs for compensating for herbivory also differ with elevation. A plant can more easily compensate for the damage when it has plentiful resources. So it may not be overall herbivory but rather the relative costs, which drives plant defences along the elevational gradients (e.g. Pellissier et al. 2016).

There is a growing evidence that such generalities are not consistent across space, time and interacting resource gradients. Various patterns of arthropod abundance have been observed along elevational gradients. Some studies report highest arthropod abundance at low elevations (e.g. Collins 1980, Wolda 1987), while others show highest summer arthropod abundance at mid-elevations (Janzen 1973, Ghosh-Harihar 2013).

Similarly, studies along elevational gradients report a variety of patterns including decreasing (e.g. Louda 1982, Galen 1990, Kelly 1998, Alonso 1999, Poveda et al. 2012, Suzuki et al. 2013, Metcalfe et al. 2014, Hülber et al. 2015), increasing (e.g. Koptur 1985, Erelli et al. 1998, Hagen et al. 2007, Bito et al. 2011, Altmann \& Claros 2015, Matías \& Jump 2015, Zhang et al. 2015) or constant herbivory (Hódar \& Zamora 2004, Bito et al. 2011, Lay et al. 2013). Generally, conclusions about arthropod herbivory along elevational gradients are far from definitive, and there is growing evidence that results are not consistent across time and space (Andrew et al. 2012, Moreira et al. 2018). Recent review called not only for critical reevaluation of the evidence for geographic gradients in plant-insect herbivore interactions, but also for development of a new mechanistic framework for predicting the patterns that do exist (Moreira et al. 2018).

A major issue with assessing arthropod herbivory along environmental gradients is the variation among plant species sampled within a gradient. Species replacement along large-scale gradients preclude comparisons of intra- and inter-specific patterns at the same scale (Johnson \& Rasmann 2011, Anstett et al. 2016). There is usually a complete turnover of 
plant species along long elevational gradients, from lowlands to alpine areas. Restricting analysis to a single widespread host plant species is only a partial solution to this problem (e.g. Zhang et al. 2015), as it will limit the gradient length available for the study. In some studies, a plant community was studied for leaf herbivory (Bito et al. 2011) and mixed approach (i.e. community-wide survey and closer focus on a species with long range) was used in others (Weissflog et al. 2017). The observed patterns differed in the two types of studies. While a species-focused studies reported usually more complex patterns (Moreira et al. 2018, Weissflog et al. 2017), the community-wide studies reported decreasing patterns more often (Moreira et al. 2018). Some species occupy long elevational gradients, but still have peak abundances within a particular elevation. This peak might lead to increased herbivory due to the increased apparency of the plant species, or decreased herbivory due to increased selection for plant defence (Moreira et al. 2018, Weissflog et al. 2017). Local adaptations and changes in plant defences along the gradient might therefore be quite important, adding complexity to the pattern.

The higher herbivory rates at lower elevations were often detected even though lowland tropical leaves are less nutritious and better defended (Coley \& Aide 1991, Pellissier et al. 2012, Pellissier et al. 2016, Galmán et al. 2018). Mature lowland tropical leaves have significantly lower foliar nitrogen and water, and higher concentrations of tannins (Coley \& Aide 1991) than those from higher elevations. Tropical young leaves have further several novel types of defences (delaying greening, extrafloral nectaries (Coley \& Kursor 1996)). Since both mature and young leaves of lowland tropical species are better defended, the higher rates of herbivory in tropical lowlands were hypothesised to reflect overall herbivore pressure (Coley 1998). This hypothesis was confirmed by Garibaldi et al. (2011) in South America but not by Bito et al. (2011) in Australia. 
Specific leaf area (SLA) and trichome density is often considered to be a surrogate for leaf thickness and toughness, which is also frequently correlated with water content (Groom \& Lamont 1999), as parameters of leaf morphology with a possible impact on leaf-chewing insects. Low SLA is believed to be an adaptation to harsh abiotic conditions. having high SLA values where resources are plentiful, a plant can escape competition for light (Kergunteuil et al. 2018). Specific leaf area was previously shown to decrease with increasing elevation and correlate positively with herbivore damage (Garibaldi et al. 2011, Pellissier et al. 2012). Leaf chemistry and physiological traits can substantially change along the gradient even among conspecific plants (Maschinski 1989, Renwick et al. 2001, Külheim et al. 2011). High concentrations of phenolic compounds may deter insect feeding, reduce insect growth and survivorship, and reduce herbivore densities and herbivore species richness (Rossiter et al. 1988, Forkner et al. 2004). However, the changes in plant quality with respect to elevation and importance of individual aspects of plant quality are species-specific and still largely unknown. Further, leaf chemistry and physiological traits can substantially change along the gradient even among conspecific plants (Maschinski 1989, Renwick et al. 2001, Külheim et al. 2011).

Results of our colleagues (Volf et al. 2018) suggest that it is mainly the diversity of secondary metabolites that drove insect community structure on Ficus plants but not their total content. Some other studies also reported that while the total content of phenolics had little effect on larval leaf-chewers, polyphenol oxidative activity (which represents polyphenol capacity to cause oxidative stress to insects) affected whole communities of larval leaf-chewers (Dyer et al. 2003, Salminen \& Karonen 2011).

Our objective was to quantify the effects of elevation on herbivorous damage, and to find out whether the herbivory damage correlates with the host defences, and if abundances 


\section{Materials and methods}

We performed the study along the Mt. Wilhelm elevational gradient in the Central Range of Papua New Guinea. The surveyed part of the transect, ca. $25 \mathrm{~km}$ long, comprises six study sites spaced regularly at 500 elevational metre intervals, from the lowest study site located within the lowland floodplains of the Ramu River at $200 \mathrm{~m}$ a.s.l. $\left(05^{\circ} 44^{\prime} \mathrm{S}, 145^{\circ} 20^{\prime} \mathrm{E}\right)$ to the elevational limit of Ficus distribution at $2700 \mathrm{~m}$ a.s.l. $\left(05^{\circ} 48^{\prime} \mathrm{S}, 145^{\circ} 09^{\prime} \mathrm{E}\right)$. Mean annual temperature (measured by data loggers Comet R3120 placed in forest understorey) decreases from $27.4^{\circ} \mathrm{C}$ at the lowland site to $8.37^{\circ} \mathrm{C}$ at the tree line at a constant rate of $0.54^{\circ} \mathrm{C}$ per 100 elevational metres (see Sam et al. 2019 for more detail). Air humidity measured by the same dataloggers ranged between 90 and 100\% at all elevations, however the rainfall was not evenly distributed during the year (see Sam et al. 2019 for more detail). Average annual precipitation is $3,288 \mathrm{~mm}$ (measured at local meteorological station, data provided by Phil Shearman) in the lowlands, rising to $4,400 \mathrm{~mm}$ at 2,700 $\mathrm{m}$ a.s.l., with a distinct condensation zone between 2,500 and 2,700 $\mathrm{m}$ a.s.l. (Sam et al. in prep). Mean monthly precipitation along the gradient is $315 \mathrm{~mm}$, and mean monthly precipitation between the two survey (i.e. wet season) periods was $398 \mathrm{~mm}$. The elevational gradient, further description of study sites, climatic and habitat characteristics are published elsewhere (Tvardikova 2013, Sam \& Koane 2014, Sam et al. 2015, Sam et al. 2019). 
Unfortunately, no tree genus was distributed along the entire elevational gradient. Therefore, we selected species from the widely distributed genus Ficus (Moraceae) as a model system, which allowed us to work from the lowlands up to $2,700 \mathrm{~m}$ a.s.l. $\left(05^{\circ} 48^{\prime} \mathrm{S}\right.$, $145^{\circ} 09^{\prime} \mathrm{E}$, Table 1). Ficus is an exceptionally species-rich genus, with New Guinea as the center of its diversity (Ronsted et al. 2008). Ficus also has high diversity (at least 75 species) and abundance (typically $>5 \%$ of stems with $\mathrm{DBH} \geq 1 \mathrm{~cm}$ ) along the Mt. Wilhelm elevational gradient (L. Sam, unpubl. data). Ficus has an upper elevational limit at 2,900 m a.s.l at Mt. Wilhelm, as well as elsewhere (Berg \& Corner 2005). Some species of Ficus (e.g. F. hahliana Diels, 1935) have particularly wide elevational ranges (Berg \& Corner 2005).

We selected and tagged experimental saplings belonging to $4-6$ evergreen Ficus species at each elevational study site (Table 2). As far as possible, we selected the locally most common species which had also broad elevational ranges. The selected plant species did not produce any exudates or sugar droplets attracting ants. We selected between 14 and 20 saplings per elevational study site, i.e. 3 - 5 per plant species and elevation or 105 saplings along the gradient (Table 2). For statistical independence, we allowed at least $80 \mathrm{~m}$ between any pair of individuals. We visually assessed saplings of the focal species and selected individuals that looked similar, had approximately 500 leaves growing within a well-developed crown $2.5-4 \mathrm{~m}$ above the ground. The saplings did not have any ant nests and did not have any abnormally high herbivory or fungal damage. Average leaf-sizes of the selected species ranged from 16.31 to $154.10 \mathrm{~cm}^{2}$, and two species (Ficus arfakensis King, 1888 and F. endochaete Summerhayes, 1941) had significantly different sized leaves at some elevations (Table 2).

At the beginning of the experiment, at the end of the dry season between 31-Aug2014 and 3-Nov-2014 (Table 1), we first collected all arthropods (described below). Then we 
counted all leaves present at the sapling (to be able to estimate the total leaf area of the sapling) and further we proceeded with collection of leaves for herbivory measurement. To assess herbivore damage, we randomly selected two branches (with ca. 30 leaves each; $57 \pm$ 5.6 (mean \pm SE) in total per sapling, i.e. up to ca. $15 \%$ of standing foliage) per sapling. We clipped these two branches and collected all leaves from them. This survey period denotes the first point measurement $(t=0)$ of herbivore damage. A branch clipping (i.e. simulation of an artificial herbivory by a vertebrate herbivore) from a grown sapling should have only short-term and non-significant effect on subsequent herbivory measurement and plant growth in our experiment (Strauss et al. 1996, Seldal et al. 2017).

Using a $50 \times 50 \mathrm{~cm}^{2}$ white backgrounds, we took photographs of all collected and flattened leaves from each sapling (i.e. we took as many photos as needed to photograph all collected leaves). Using Adobe Photoshop CS6 (Adobe Systems Inc., USA). We first outlined the missing edges on the photographed leaves based on the expected shape and whitened or blackened various damages or holes on the leaves. Using various guides, google image searches, and our previous expertise, we carefully distinguished leaf damage caused by chewing and mining herbivores (which was whitened), while we did not consider fungal damage or mechanical leaf damage (which we blackened). We then turned the photos to black and white pictures. We used ImageJ version 1.47 (National Institute of Health, USA) to calculate the remaining leaf area $\left(\mathrm{a}\right.$, in $\left.\mathrm{cm}^{2}\right)$, the extrapolated leaf area without any herbivore damage (b), and the area lost to herbivory $(c=b-a)$. We then estimated the percentage of leaf-area loss as c/b x 100. We calculated the herbivory loss as loss in $\%$ of are per leaf and in $\mathrm{cm}^{2}$ per $100 \mathrm{~cm}^{2}$. These two values were highly correlated, so we used only $\%$ of herbivory per leaf in analyses and figures. 
We conducted a second survey of herbivore damage, on the very same saplings as used in the first survey, approximately six months after the first survey (between 21-Mar2015 and 11-May-2015, Table 1) at the end of the rainy season of 2014/2015. Similarly, to the first survey, we conducted the arthropod collection first. Then we collected all leaves from each sapling into a bag. We randomly selected 55-60 of leaves (to match the samples size of the first survey), photographed them on the same white background as earlier, and analysed them in the same way as in the first survey.

After each survey, we obtained values for $57 \pm 5.6($ mean $\pm S E$, $\min =50$, $\max =95)$ leaves per sapling. We weighed all scanned and the remaining leaves to calculate the total leaf area for each sapling from the second survey. We used measured mean leaf size per sapling multiplied by the calculated number of leaves on sapling to obtain total leaf area of the sapling the beginning of the experiment (first survey) The amount of herbivore damage was assessed blindly; viz. the field collector (BK) and the research assistant (AM) handling the leaves did not know that the study aimed to measure leaf damage, preventing any bias in leaf selection.

We measured herbivory on at least three saplings of each plant species at each elevational study site (Table 2) and in average of 438 leaves per plant species and elevation (or $114 \pm 11.8$ leaves per sapling), which is a number recommended by previous studies (Zhang et al. 2015, Kozlov \& Zvereva 2017). By analysis of 11,448 leaves, our study belongs to those larger (Bito et al. 2011, Metcalfe et al. 2014, Kozlov \& Zvereva 2017). The number of individual saplings sampled per species and elevational study site seemed to be sufficient as their herbivory between individuals did not differ significantly in majority of cases (Table S1) and the model with tree number as a random effect differed only marginally from model 
without random effect $(\mathrm{AIC}=2.12)$. We therefore decided to use mean herbivory per species at each elevation and survey in further analyses.

\section{Arthropod survey}

Arthropod censuses were performed destructively during both surveys at the same individuals that were used for herbivory measurements, just before we started measurements of herbivorous damage and leaf collections. We slowly lowered the trunk of the sapling above a mosquito net, wrapped it to the mosquito net and sprayed with fast knock-down insecticide (Mortein $\left.{ }^{\circledR}\right)$. After a while, we shook foliage firmly, opened the net and collected all arthropods ( $>1 \mathrm{~mm})$ and preserved them in vials filled with DNA grade ethanol. In laboratory, arthropods were counted, identified into three feeding groups (i.e. "chewing herbivores", "predators", "other arthropods" who have no relationship to herbivorous damage as we measured it and do not act as mesopredators - e.g. adult flies, pupae, adult Lepidoptera etc., sap sucking herbivores). Abundances of chewing herbivorous arthropods was then calculated as number of individuals in feeding guild per $\mathrm{m} 2$ of leaf area.

\section{Plant defensive trait measurements}

We measured plant defensive traits for two plant species (out of the 8 surveyed for herbivory). For each of these two species at each elevation, we collected leaf discs from five individuals. Where possible, the same individuals were used for herbivory and insect survey and trait measurements, but up to two individuals per plant species and elevation were sampled from different individual. These were usually individuals with smaller amount of leaves than was acceptable for the herbivory and herbivore survey. We collected two $4.5 \mathrm{~cm}^{2}$ leaf discs per leaf 
from 20 young, but fully expanded leaves for each individual, avoiding the central vein $(1 \mathrm{~g}$ of dry weight in total on average). The discs were air-dried and stored in silica gel. Half of them were used for the analysis of triterpenes and half of them for measurement of physical traits.

Physical Traits: We measured trichome density and specific leaf area (SLA). Trichome density and SLA are parameters of leaf morphology with a possible impact on leaf-chewing insects. The total number of trichomes per $10 \mathrm{~mm}^{2}$ and their average length was measured on five leaf discs per individual using ImageJ (ver.1.48). Values for dorsal and ventral sides of the discs were combined. Specific leaf area (SLA) was calculated as the area per unit mass of five dried leaf discs collected from five leaves of known diameter for each individual.

Triterpene analysis: Dried powdered leaf tissue samples were ground with methanol in TissueLyser. Then they were centrifugated and aliquot was saved for further use. Terpenoids in aliquot were measured on a Dionex Ultimate 3000 LC system equipped with an Open XRS autosampler and coupled to a Q Exactive Plus Orbitrap mass spectrometer (Thermo Fisher Scientific, San Jose, CA, USA). A reversed phase Kinetex was used for separating the analytes. For further measurement details, refer to the Methods S1 in Supplementary information.

Data analysis

We calculated the herbivory as (a) loss in \% of are per individual leaf and in (b) $\mathrm{cm}^{2}$ per $100 \mathrm{~cm}^{2}$. Actual leaf area damaged (in $\mathrm{cm}^{2}$ per $100 \mathrm{~cm}^{2}, \log$ transformed) should have statistically higher power than arcsine-transformed proportional data (Warton \& Hui 2011), and were previously recommended for analyses of herbivore damage, while most of the authors usually report percentage of the area damaged. The results for herbivory measured 
as leaf area (in $\mathrm{cm}^{2}$ denominated by leaf size, binomial distribution, logit link function) showed the same patterns (Fig. S1 and Table S1) and results (Study sites: Dev. $=2.54, \mathrm{df}=5$, $\chi^{2}<0.001$; Species: Dev. $=24.87, \mathrm{df}=13, \chi^{2}<0.001$; Survey: Dev. $\left.=0.51, \mathrm{df}=1, \chi^{2}<0.081\right)$ as the herbivory measured in \%. Because the results did not differ significantly, and we observed no overdispersion in our data on herbivore damage measured in \% and arcsinetransformed, we decided to report only results for percentages of herbivore damage from here onwards; which is common practice for most authors. The arcsine square root transformed percentages of the leaf area damaged by arthropod herbivores, met the normality assumption.

To investigate the main effects (elevation, season and plant species) along the elevational gradient, we ran a Generalized Linear Mixed-effect Model (GLMM; with Gaussian family and identity link function for arcsine-transformed percentage data and with binomial family and logit link function for actual damaged area data; McCullagh and Nelder 1989) with elevation, plant species and season as the explanatory variables, tree number as a random effect, and herbivory as the response variable. The GLMM model using percentage data did not suffer from over-dispersion as might sometimes happen (Warton \& Hui 2011). We ran Tukey Posthoc-tests ('glht' function, 'multcomp' package) to compare individual species or elevational study sites. Pearson's correlations were run to correlate the data from herbivory, plant traits or arthropod abundances ('cor.test' function). We deposited all data with Dryad: https://doi.org/10.5061/dryad.kwh70rz06.

\section{Results}

We analysed herbivore damage on 11,448 leaves from 105 saplings belonging to 8 Ficus species (Table 2, Table S1) occurring naturally between 200 and 2,700 $\mathrm{m}$ a.s.l. of the 
elevational gradient of Mt. Wilhelm. The overall proportion of consumed leaf area during the first survey of herbivory was $2.22 \pm 0.14 \%$ (mean \pm SE) and $2.62 \pm 0.12 \%$ during the second survey. This corresponds approximately to $1.4 \pm 0.06 \mathrm{~cm}^{2}$ per one leaf and $2.44 \pm 0.09$ $\mathrm{cm}^{2}$ per $100 \mathrm{~cm}^{2}$ of leaf area (mean $\pm \mathrm{SE}$, Fig. S1). We found significant variation in herbivore damage (measured as \% of leaf area lost, arcsine-transformed) among the six elevational study sites $\left(\right.$ Dev. $\left.=1.14, \mathrm{df}=5, \chi^{2}<0.001\right)$ and among tree species $\left(\right.$ Dev. $=3.57, \mathrm{df}=13, \chi^{2}<$ 0.001). Herbivory differed marginally significantly between the two surveys conducted six months apart (Dev. $=0.09, \mathrm{df}=1, \chi^{2}=0.052 ;$ Fig. 2, Fig. S1 and Table S1).

The mean (weighted mean herbivory per plant species across the both surveys) proportional foliar losses to arthropods measured was highest at $700 \mathrm{~m}$ a.s.l. $(3.73 \pm 0.53 \%)$, followed by $1200 \mathrm{~m}$ a.s.l. (3.08 $\pm 0.38 \%$; Fig. $2 \mathrm{~b}), 1700 \mathrm{~m}$ a.s.l. $(2.48 \pm 0.19 \%)$ and by $200 \mathrm{~m}$ a.s.l. $(2.25 \pm 0.17 \%)$.

Losses of plant foliage varied significantly among plant species within $200-1700 \mathrm{~m}$ a.s.l. $\left(\chi^{2}=21.09-9.56, \mathrm{P}=0.048-<0.001\right)$ study sites along the elevational gradient of Mt. Wilhelm. As an example, we present herbivore damage on four plant species at $200 \mathrm{~m}$ a.s.l. (Fig. 3, $\chi^{2}=9.56, \mathrm{P}=0.048$ ). In Kausi, the leaf sizes of the Ficus trees studied ranged between $38-180 \mathrm{~cm}^{2}$.

We found some variation in the elevational trends in herbivory among plant species occurring at more than one elevation (Fig. 4, F. hahliana vs. F. trichocerasa $\mathrm{P}=0.04 ; F$. iodotricha vs. F. hahliana $\mathrm{P}=0.06$, vs. F. saccate $\mathrm{P}=0.04)$. Herbivory damage of $F$. hahliana, the species with the longest elevational distribution (between 200 and $2700 \mathrm{~m}$ a.s.1.), was significantly higher at $200-700 \mathrm{~m}$ a.s.l. compared to $1200-2700 \mathrm{~m}$ a.s.l. (Fig. 4). Generally, herbivore damage on species occurring at low elevations peaked at $700 \mathrm{~m}$ or $200 \mathrm{~m}$ a.s.l. and then decreased. Herbivory decreased with increasing elevation in the majority of species 
occurring at elevations above $1700 \mathrm{~m}$. Herbivore damage did not change significantly between elevational study sites in several species (Fig. 4), while the non-overlapping elevational ranges did-not allow comparisons of patterns between some plant species.

\section{Herbivorous damage vs. abundances of herbivores}

Mean abundances of arthropods on saplings of individual plant species did not differ significantly but were slightly higher (1.25 times) at the end of the rainy season than at the end of dry season (Table 1, Figure 2) and this was true at all elevational study sites (Survey: $\mathrm{F}_{1,183}=12.09, \mathrm{P}<0.001$; Survey*Plant species: $\mathrm{F}_{8,183}=0.64, \mathrm{P}=0.791$, Survey ${ }^{*}$ Site: $\mathrm{F}_{5,183}=0.21$, $P=0.791)$. Plant species in interaction with elevational study site, but not elevational study site alone, had significant effect on the observed abundances of herbivorous arthropods (Plant species ${ }^{*}$ Site: $\mathrm{F}_{12,183}=3.687, \mathrm{P}=0.049$, Site: $\mathrm{F}_{5,183}=0.759, \mathrm{P}=0.58$ ). The positive relationship between the mean values for herbivorous damage and abundance of herbivorous arthropods for the plant species on specific elevations were significant (Survey 1: $r=0.490, p=0.005$, Survey $2: r=0.506, p=0.004 ; N=27$ for each survey). However, abundances of herbivorous arthropods and herbivorous damage at individual saplings did not correlate significantly (Survey 1: $\mathrm{r}=0.013, \mathrm{p}=0.898$; Survey 2: $\mathrm{r}=0.043, \mathrm{p}=0.763 ; \mathrm{N}=105$ for each survey).

Herbivorous damage vs. plant defences

Most host-plant defences measured for the two Ficus species showed non-linear correlations with elevation and had a hump-shaped distribution along the gradient (Fig. 5). However, specific elevational trends in the defensive traits studied here differed between Ficus hahliana and F. arfakensis. In the case of both species, triterpene diversity correlated negatively 
significantly with herbivorous damage (Table S2). Trichome density correlated significantly positively with herbivorous damage of $F$. arfakensis but negatively with herbivory of $F$. hahliana. The triterpene content of F. arfakensis decreased non-linearly towards higher elevations with the maximum at $700 \mathrm{~m}$ and was positively correlated with herbivory.

\section{Discussion}

Insect herbivory is an interaction with main consequences for ecosystem functioning. Direct effects of herbivory on ecosystem are via nutrient cycling, indirect effects involve effects on plant species composition including succession, on plant resource allocation and on food web interactions. We aimed to quantify the effects of elevation on herbivorous damage, and to find out whether the herbivory damage correlates with the host defences, and if abundances of herbivorous insects correlated directly with herbivorous damage. In concordance with our predictions, we found correlation between abundance of herbivorous arthropods and herbivory damage at plant species and site level, but not at the level of individual saplings. We assume that this is because while arthropods are mobile, and collected at one point in time, herbivorous damage accumulated in time reflects their presence in past. For the two plant species studied in detail, we observed rather tight correlations between plant defences and herbivory damage, which would mean that absolute values of the damage drive the defences.

In contrast to previous studies of herbivory, we found much lower herbivory damage, $2.4 \%$ of leaf area, than reported in previous studies. Our value is more than 10 times lower than the average values reported for tropical regions in several highly cited review papers (from 11.1 to $48.0 \%$, measured usually at one time point (Coley \& Aide 1991, Cyr \& Face 1993, Coley \& Kursor 1996) but see (Suzuki et al. 2013; reporting 1.6-8.7\% herbivory from 
Borneo)). Even along the same elevational gradient, some species suffer considerably higher herbivory than other. e.g. Plowman et al. (2017) 20 - 40\% damage per individual leaf. Kozlov et al. (2014) found that blind measurements (i.e. where assistants/researchers naïve to the purpose of the study or to treatment conduct the measurements) of herbivore damage demonstrated that woody plants in Brazil lose, on average, $1.11 \%$ of their leaf area to defoliating arthropods. Zava \& Cianciaruso (2014), working with numerous plant species in Emas National Park in Brazil, also reported that community-wide losses of woody plants to arthropod were as low as $1.35 \%$, i.e., close to our value (2.4\%) and to Kozlov et al. (2014) $1.1 \%$ as obtained by a blind method. We support the urge for caution (Kozlov et al. 2014, Zvereva \& Kozlov 2014) in obtaining values of herbivory in non-blind experiments, often used as rough estimates, and in obtaining community-wise characteristics from the results of single-species studies.

Along a tropical elevational gradient, we found a peak in herbivory at lower midelevations and a decrease towards the lowlands and higher elevations. This trend of decreasing herbivory seems to continue even to higher elevations (up to $3700 \mathrm{~m}$ ) if we consider non-Ficus species, which we measured by exactly the same methods, above the elevational distributional limits of Ficus at Mt. Wilhelm gradient (Figure S1). Herbivory as a subject has been studied along elevational gradients at least 17 times already, with the majority of research coming from the temperate regions and usually from short elevational gradients, where the mean length was 700 elevational $\mathrm{m}(\min =500, \max =4025 \mathrm{~m})$. The majority (63\%) of previously published studies on trends in herbivory along elevational gradients reported an overall decreasing trend with increasing elevation, while $25 \%$ reported increasing trends and the rest found no trend in herbivory (Zvereva \& Kozlov 2014). Two studies most closely comparable to ours showed (reporting chewing herbivory 
along a tropical gradient of similar length) that herbivory increased with elevation (Koptur 1985, Zhang et al. 2015). Similarly to other studies, we focused solely on the damage caused by chewing arthropods, as one of the herbivore guilds which generally causes the highest damage to plants (Schoonhoven et al. 2005). This was also largely because mines and galls were relatively rare at our study sites, and generally hard to find at the low forest strata where we measured herbivory. We report a unimodal elevational trend in herbivory with a peak at $700 \mathrm{~m}$ a.s.l. at the plant community level, but several different patterns at the plant species level.

When considering previously known chemistry and our own data, we might conclude that none of the eight species included is especially well protected in comparison to some other species of Ficus (Xiang \& Chen 2004). For example, some sympatric New Guinean species contain latex with higher proteolytic activity and higher concentrations of triterpenes than the species studied here (e.g. F. subtrinervia and F. rubrivestimenta) (Volf et al. 2018). However, we should keep in mind, that they might rely on other on different forms of defences. In particular, F. trachypison and F. concocephalifolia have low protease activity and a low concentration of triterpenes compared to these species (Volf et al. 2018). For example, F. hahliana has significantly higher herbivory at $200-1200 \mathrm{~m}$ (Fig. 4) but appears to be better defended at higher elevations as leaves have a higher density of trichomes, higher triterpene diversity and lower specific leaf area at elevations above $1500 \mathrm{~m}$ (Fig. 5). The surprising hump-shaped pattern in herbivory seen in F. arfakensis also corresponds to leaves with lower triterpene diversity and higher specific leaf area, but trichome density is highest at the middle elevations in this species. This shows that individual defensive traits show varying responses to elevation and their relative importance in terms of anti-herbivore protection may differ between elevations (Pellissier et al. 2016). Further, our results confirm that 
different plant species have different defensive strategies against herbivory at different elevations, but the causality is difficult to assign in some cases. We still do not know whether variation in defensive traits is driven by herbivory or whether herbivory is related to defensive traits that are responding to the environment. Furthermore, there are clearly trade-offs between some traits (e.g. triterpene diversity and triterpene content) which require further investigation.

We found only weakly positive relationship between the herbivorous damage and abundance of herbivorous arthropods for the plant species on specific elevations. However, herbivory and abundances of herbivores did not correlate when we focused on individual saplings. In a different study, levels of herbivory were not related to beetle abundance, whereas it was significantly negatively related to beetle species richness (Bito et al. 2011). Overall, the abundances of herbivorous insect tend to peak at mid-elevations of the gradient, where most favourable conditions are seen. Water availability (measured as air humidity and rainfall) is high there due to condensation zone, and temperatures still relatively high and suitable for growth of dense and tall vegetation (Sam et al. 2019). The observed humpshaped pattern in abundances of herbivorous insect might be also partly driven by high predation at low elevations (Sam et al. 2015) and unfavourable climatic conditions at high elevations. Similarly to herbivorous damage, abundances of insect were higher during the second survey, which corresponded with higher herbivorous damage reported during that survey too. This might imply, that climate (especially water availability in case of our gradient) might have significant effect on changes in herbivory and herbivore abundances. If a climate change happens, insect herbivores are likely to react faster than plants (Robinet \& Roques 2010), which might lead to a movement of herbivores to higher elevations, where plants have different (lower) defences or where it will be more difficult for them to 
compensate for herbivorous damage. Colwell et al. (2008) showed that extinction due to upland shifts can be true for tropical insects. Using data collected for 1,902 species of insects and plants along an altitudinal transect in Costa Rica, they showed that a high proportion of tropical species analysed ( $\approx 53 \%)$ may be faced with range-shift gaps and might face extinction with a $1000 \mathrm{~m}$ range shift in isotherms. Based on our data, which elevational distributions of several Ficus species, would surely support this finding. Many arthropod species dependent on specific Ficus species would disappear, if they are pushed to different locations due to climate change.

While this study was conducted in 2014, a strong El Niño event occurred in 2015 and affected mostly lowland sites (200 and $700 \mathrm{~m}$ a.s.l.) of Mt. Wilhelm gradient by severe droughts and extremely high temperatures $\left(2.1^{\circ} \mathrm{C}\right.$ higher than average for those months). During the El Niño, we observed significant drop in abundances of insect and insectivorous birds at these lowland sites (Sam et al. in prep.). The drop was at the lower range of the drop observed in Puerto Rican forest, where arthropod biomass fell 10 to 60 times after temperatures increased by $2.0^{\circ} \mathrm{C}$ (Lister and Garcia 2018). For many insect herbivores, synchronization to plant phenology is crucial. We can only guess whether the insect changed their phenology temporarily or move quickly to higher elevations.

Our study suffers from a lack of information on leaf longevity and the lack of information about the fate of individual leaves (without tagging and following individual leaves, we miss information about the leaves that disappear completely). The importance of leaf longevity for the interpretation of single-point measurements of herbivory depends on the way the herbivore damage accumulates during the lifetime of the leaf. At one extreme, it is believed that, almost all damage is acquired when the leaf is young so that the subsequent leaf life span is irrelevant. This might be because the aging leaves accumulate chemical 
compounds and strengthen mechanical defences (e.g. Kouki et al. 2002, Read et al. 2003). At the other extreme, herbivory might be accumulated steadily throughout the entire leaf life span and is therefore proportional to lifespan (Sand-Jensen et al. 1994). The data from tropical forests suggest the former scenario is a more realistic one (e.g. Kursar \& Coley 2003). We therefore believe that our point measurements of standing damage report overall herbivory relatively precisely. Along elevational gradients in tropical areas, leaf-longevity has been shown to increase with elevation (Kikuzawa 1996). Another study showed that species native to Amazonian forests had average leaf life spans that differed according to forest structure, e.g. of 3.2 years in shaded understory, 1.9 years in small gaps, and 1.6 years in sunlit mature canopy trees (Reich et al. 2004). We should also keep in mind that some plants drop damaged leaves earlier than undamaged leaves (Faeth et al. 1981), and very little is known about this phenomenon in Ficus.

The ecological and evolutionary importance of plant-herbivore interactions is widely appreciated. However, is herbivory as low as 1-2\% still significant? In an experiment in temperate region, the annual removal of $2,4,8$ and $16 \%$ of the leaf area from naturally growing mountain birch Betula pubescens saplings during a seven-year period resulted in a pronounced reduction of plant vertical growth $(-30,-34,-45$ and $-78 \%$, respectively; Zvereva et al. 2012). Leaf size decreased first, followed by a considerable decrease in the length of long shoots in all treatments (Zvereva et al. 2012). Marquis (1992) found that $10 \%$ experimental defoliation of an understory shrub, Piper arieianum, reduced growth and seed production, delayed flowering, and decreased seed viability. Annual survivorship was $85 \%$ for undamaged seedlings of Dipteryx panamensis and 0\% for seedlings with $8 \%$ of their leaf area missing (Clark \& Clark 1985). Sixty-five percent of the species surveyed in the 
understory of the Los Tuxtlas tropical rain forest had an average leaf area damage per plant of less than $1 \%$ (range: $0.25-20.52 \%$ ).

Besides the direct effect on saplings, herbivory can also cause very important indirect damage via pathogens. A survey showed that $43 \%$ of the leaves were damaged by herbivores and pathogens concurrently, 16\% showed damage by insect herbivory alone, and only $1.4 \%$ of the sampled leaves showed damage by pathogens alone (García-Guzmán \& Dirzo 2001). This mean that pathogens transmitted by herbivores represent serious problem even for plants with little herbivore damage. Hence, herbivory may have real and substantial direct and indirect impacts on the growth and survival of plants, especially in their younger stages. This impact might be more substantial in the tropics than in the temperate zone (García-Guzmán \& Dirzo 2001), as 68\% of lifetime herbivory of tropical shade-tolerant species occurs during the small window of leaf expansion (a 1-3 week long period).

We found the community-wide herbivorous damage to peak in lower mid-elevations of the $2700 \mathrm{~m}$ long elevational gradient, and we found correlation between species-specific herbivorous damage at each elevation and abundance of herbivorous insect. Further, we found correlations between herbivorous damage and species-specific plant defences. We conclude, that the plant traits, communities of herbivores and herbivory are likely to be affected by climatic conditions at specific elevations. Along our tropical elevational gradient, where temperature is generally high, decreasing linearly, the water availability seemed to shape the relationships between plants and arthropods. In lowlands, where more distinct dry and wet seasons occur, the total abundances of insect were lower than at middle elevations, where temperatures are still relatively high but humidity higher and dry seasons not so distinct. At highest elevations (above $2200 \mathrm{~m}$ a.s.l.) the low temperatures seem to 
cause low abundances and diversity of insects (Sam et al. 2019). and After the rainy season, the herbivory was significantly higher at upper three study sites only but not at lower three study sites than during the first, dry-season, survey.

\section{Acknowledgement}

KS acknowledges Grant Agency of Czech Republic project 18-23794Y and ERC grant No. 805189. STS acknowledges funding from and a USB Postdoc project (reg.no.

CZ.1.07/2.3.00/30.0006) (funded by the EU Education for Competitiveness Operational Programme, the European Social Fund and the Czech State Budget), MV acknowledges the Grant Agency of University of South Bohemia (GAJU 04-152/2016/P), VN was funded by the ERC grant No. 669609, BK was funded by the Darwin Initiative for the Survival of Species (14-054) and the Christensen Fund (2016-8734).

\section{DATA AVAILABILITY}

Data available from the Dryad Digital Repository:

https://doi.org/10.5061/dryad.kwh70rz06 (Sam et al. 2019).

\section{References}


Adams, J. M., Y. Zhang , M. Basri, and N. Shukor. 2009. Do tropical forest leaves suffer more insect herbivory? A comparison of tropical versus temperate herbivory, estimated from leaf litter. Ecological research 24: 1381.

Alonso, C. 1999. Variation in herbivory by Yponomeuta mahalebella on its only host plant Prunus mahaleb along an elevational gradient. Ecological Entomology 24: 371-379.

Altmann, S. H., and S. Claros. 2015. Insect abundance and damage on the deciduous Nothofagus macrocarpa increase with altitude at a site in the Mediterranean climate zone of Chile. Austral Entomology.

Andrew, N. R., I. R. Roberts, and S. J. Hill. 2012. Insect herbivory along environmental gradients. Open Journal of Ecology 2: 202.

Anstett, D. N., K. A. Nunes, C. Baskett, and P. M. Kotanen. 2016. Sources of controversy surrounding latitudinal patterns in herbivory and defense. Trends in ecology and evolution 31: 789-802.

Beck, J., G. Brehm, and K. Fiedler. 2011. Links between the environment, abundance and diversity of Andean moths. Biotropica 43: 208-217.

Berg, C., and E. Corner. 2005. Moraceae: Ficeae. Flora Malesiana-Series 1, Spermatophyta 17: $1-702$.

Bito, D., V. Novotny, C. J. Burwell, A. Nakamura, R. L. Kitching, and F. Ødegaard. 2011. Predator pressure, herbivore abundance and plant damage along a subtropical altitudinal gradient. Memoirs of the Queensland Museum 55.

Brehm, G., D. Süssenbach, and K. J. E. Fiedler. 2003. Unique elevational diversity patterns of geometrid moths in an Andean montane rainforest. Ecography 26: 456-466.

Clark, D. B., and D. A. Clark. 1985. Seedling dynamics of a tropical tree: impacts of herbivory and meristem damage. Ecology: 1884-1892. 
Coley, P. D. 1998. Possible effects of climate change on plant/herbivore interactions in moist tropical forests. Climatic change 39: 455-472.

Coley, P. D., and T. M. Aide. 1991. Comparison of herbivory and plant defences in temperate and tropical broad-leaved forests, in plant-animal interactions: Evolutionary ecology in the tropical and temperate regions. John Wiley \& Sons Ltd., , Brisbane.

Coley, P. D., and J. Barone. 1996. Herbivory and plant defenses in tropical forests. Annual Review of Ecology and Systematics: 305-335.

Coley, P. D., and T. A. Kursor. 1996. Anti-herbivore defenses of young tropical leaves: physiological constraints and ecological trade-offs. Tropical forest plant ecophysiology, 305336.

Collins, N. J. O. 1980. The distribution of soil macrofauna on the west ridge of Gunung (Mount) Mulu, Sarawak. Oecologia 44: 263-275.

Colwell, R.K., G., Brehm, C.L., Cardelús, A.C. Gilman, and J.T., Longino, 2008. Global warming, elevational range shifts, and lowland biotic attrition in the wet tropics. science 322: $258-261$

Cyr, H., and M. L. Face. 1993. Magnitude and patterns of herbivory in aquatic and terrestrial ecosystems. Nature 361: 148-150.

Dyer, L. A., C. D. Dodson, J. Stireman, M. Tobler, A. M. Smilanich, R. Fincher, and D. K. Letourneau. 2003. Synergistic effects of three Piper amides on generalist and specialist herbivores. Journal of chemical ecology 29: 2499-2514.

Erelli, M. C., M. P. Ayres, and G. K. Eaton. 1998. Altitudinal patterns in host suitability for forest insects. Oecologia 117: 133-142.

Faeth, S.H., Connor, E.F. and Simberloff, D., 1981. Early leaf abscission: a neglected source of mortality for folivores. The American Naturalist 117: 409-415. 
Forkner, R. E., R. J. Marquis, and J. T. Lill. 2004. Feeny revisited: condensed tannins as anti-herbivore defences in leaf-chewing herbivore communities of Quercus. Ecological Entomology 29: 174-187.

Galen, C. 1990. Limits to the distributions of alpine tundra plants: herbivores and the alpine skypilot, Polemonium viscosum. Oikos 59: 355-358.

Galmán, A., L. Abdala-Roberts, S. Zhang, J. C. Berny-Mier y Teran, S. Rasmann, and X. Moreira. 2018. A global analysis of elevational gradients in leaf herbivory and its underlying drivers: Effects of plant growth form, leaf habit and climatic correlates. Journal of Ecology 106: 413-421.

García-Guzmán, G., and R. Dirzo. 2001. Patterns of leaf-pathogen infection in the understory of a Mexican rain forest: incidence, spatiotemporal variation, and mechanisms of infection. American Journal of Botany 88: 634-645.

Garibaldi, L. A., T. Kitzberger, and E. J. Chaneton. 2011. Environmental and genetic control of insect abundance and herbivory along a forest elevational gradient. Oecologia 167: 117129.

Ghosh-Harihar, M. J. E. 2013. Distribution and abundance of foliage-arthropods across elevational gradients in the east and west Himalayas. Ecological research 28: 125-130.

Groom, P. K., and B. B. Lamont. 1999. Which common indices of sclerophylly best reflect differences in leaf structure? Ecoscience: 471-474.

Hagen, S. B., J. U., Jepsen, A. R. Ims, and G. N. Yoccoz. 2007. Shifting altitudinal distribution of outbreak zones of winter moth Operophtera brumata in sub-arctic birch forest: a response to recent climate warming? Ecography 30: 299-307. 
Hódar, J. A., and R. Zamora. 2004. Herbivory and climatic warming: a Mediterranean outbreaking caterpillar attacks a relict, boreal pine species. Biodiversity \& Conservation 13: 493-500.

Hodkinson, I. D. 2005. Terrestrial insects along elevation gradients: species and community responses to altitude. Biological Reviews 80: 489-513.

Hülber, K., J. A. Haider, T. E. Hager, S. Dullinger, and K. Fiedler. 2015. Insect herbivory in alpine grasslands is constrained by community and host traits. Journal of Vegetation Science.

Jamieson, M. A., A. M. Trowbridge, K. F. Raffa, and R. L. Lindroth. 2012. Consequences of climate warming and altered precipitation patterns for plant-insect and multitrophic interactions. Plant physiology 160: 1719-1727.

Janzen, D. H. J. E. 1973. Sweep samples of tropical foliage insects: effects of seasons, vegetation types, elevation, time of day, and insularity. 54: 687-708.

Johnson, M. T., and S. Rasmann. 2011. The latitudinal herbivory-defence hypothesis takes a detour on the map. New Phytologist 191: 589-592.

Kelly, C. A. 1998. Effects of variable life history and insect herbivores on reproduction in Solidago macrophylla (Asteraceae) on an elevational gradient. The American midland naturalist 139: 243-254.

Kergunteuil, A., Descombes, P., Glauser, G., Pellissier, L. and Rasmann, S., 2018. Plant physical and chemical defence variation along elevation gradients: A functional traitbased approach. Oecologia 187: 561-571.

Kikuzawa, K. 1996. Geographical distribution of leaf life span and species diversity of trees simulated by a leaf-longevity model. Vegetatio 122: 61-67. 
Koptur, S. 1985. Alternative defenses against herbivores in Inga (Fabaceae: Mimosoideae) over an elevational gradient. Ecology 66: 1639-1650.

Kouki, M., and Manetas, Y. 2002. Toughness is less important than chemical composition of Arbutus leaves in food selection by Poecilimon species. New Phytologist 154: 399-407.

Kozlov, M. V., Lanta, V., Zverev, V.E., Zvereva, E.L. 2015. Global patterns in background losses of woody plant foliage to insects. Global Ecology and Biogeography 24: 1126-1135.

Kozlov, M. V., Zverev V., and E. L. Zvereva. 2014. Confirmation bias leads to overestimation of losses of woody plant foliage to insect herbivores in tropical regions. PeerJ 2(12):e709.

Kozlov, M. V., and E. L. Zvereva. 2017. Background insect herbivory: impacts, patterns and methodology. In Progress in Botany Vol. 79 (pp. 313-355). Springer, Cham.

Külheim, C., Yeoh, S.H., Wallis, I.R., Laffan, S., Moran, G.F., and Foley, W.J. 2011. The molecular basis of quantitative variation in foliar secondary metabolites in Eucalyptus globulus. New Phytologist 191: 1041-1053.

Kursar, T., and P. Coley. 2003. Convergence in defense syndromes of young leaves in tropical rainforests. Biochemical Systematics and Ecology 31: 929-949.

Lay, C., Y. Linhart, and P. Diggle. 2013. Variation among Four Populations of Erysimum Capitatum in Phenotype, Pollination and Herbivory over an Elevational Gradient. The American Midland Naturalist 169: 259-273.

Lister, B.C. and A., Garcia, 2018. Climate-driven declines in arthropod abundance restructure a rainforest food web. Proceedings of the National Academy of Sciences 115: E10397-E10406.

Louda, S. M. 1982. Distribution ecology: variation in plant recruitment over a gradient in relation to insect seed predation. Ecological monographs 52: 25-41. 
Marquis, R. J. 1992. A bite is a bite is a bite? Constraints on response to folivory in Piper arieianum (Piperaceae). Ecology 16: 143-152.

Maschinski, J., and Whitham, T. G. 1989. The continuum of plant responses to herbivory: The influence of plant association, nutrient availability, and timing. The American Naturalist 134: 1-19.

Matías, L., and A. S. Jump. 2015. Asymmetric changes of growth and reproductive investment herald altitudinal and latitudinal range shifts of two woody species. Global change biology 21: 882-896.

Metcalfe, D. B., G. P. Asner, R. E. Martin, J. E. Silva Espejo, W. H. Huasco, F. F. Farfán Amézquita, L. Carranza-Jimenez, D. F. Galiano Cabrera, L. D. Baca, and F. Sinca. 2014. Herbivory makes major contributions to ecosystem carbon and nutrient cycling in tropical forests. Ecology Letters 17: 324-332.

Moles, A. T., S. P. Bonser, A. G. Poore, I. R. Wallis, and W. J. Foley. 2011a. Assessing the evidence for latitudinal gradients in plant defence and herbivory. Functional ecology 25: 380-388.

Moles, A. T., I.R., Wallis, W.J., Foley, D.I., Warton, J.C., Stegen, A.J., Bisigato, et al. 2011b. Putting plant resistance traits on the map: a test of the idea that plants are better defended at lower latitudes. New Phytologist 191: 777-788.

Moreira, X., W. K. Petry, K. A. Mooney, S. Rasmann, and L. Abdala-Roberts. 2018. Elevational gradients in plant defences and insect herbivory: recent advances in the field and prospects for future research. Ecography 41: 1485-1496.

Niemela, J., Y. Haila, E. Halme, T. Pajunen, and P. J. J. o. b. Punttila. 1992. Small-scale heterogeneity in the spatial distribution of carabid beetles in the southern Finnish taiga. 1: 173-181. 
Pellissier, L., K. Fiedler, C. Ndribe, A. Dubuis, J. N. Pradervand, A. Guisan, and S. Rasmann. 2012. Shifts in species richness, herbivore specialization, and plant resistance along elevation gradients. Ecology and Evolution 2: 1818-1825.

Pellissier, L., X. Moreira, H. Danner, M. Serrano, N. Salamin, N. M. Dam, and S. Rasmann. 2016. The simultaneous inducibility of phytochemicals related to plant direct and indirect defences against herbivores is stronger at low elevation. Journal of Ecology 104: 1116-1125.

Peters, M. K., A. Hemp, T. Appelhans, C. Behler, A. Classen, F. Detsch, A. Ensslin, S. W. Ferger, S. B. Frederiksen, and F. J. N. c. Gebert. 2016. Predictors of elevational biodiversity gradients change from single taxa to the multi-taxa community level. Nature communication 7: 13736.

Plowman, N. S., A. S. Hood, J. Moses, C. Redmond, V. Novotny, P. Klimes, and T. M. J. P. R. S. B. Fayle. 2017. Network reorganization and breakdown of an ant-plant protection mutualism with elevation. Proc. R. Soc. B 284: 20162564.

Poveda, K., E. Martínez, M. F. Kersch-Becker, M. A. Bonilla, and T. Tscharntke. 2012. Landscape simplification and altitude affect biodiversity, herbivory and Andean potato yield. Journal of Applied Ecology 49: 513-522.

Read, J., Gras, E., Sanson, G.D., Clissold, F. and Brunt, C., 2003. Does chemical defence decline more in developing leaves that become strong and tough at maturity? Australian Journal of Botany 51: 489-496.

Reich, P. B., C. Uhl, M. B. Walters, L. Prugh, and D. S. Ellsworth. 2004. Leaf demography and phenology in Amazonian rain forest: a census of 40000 leaves of 23 tree species. Ecological Monographs 74: 3-23. 
Renwick, J. A. A., Zhang, W., Haribal, M., Attygalle, A.B., Lopez K.D. 2001. Dual chemical barriers protect a plant against different larval stages of an insect. Journal of Chemical Ecology 27: 1575-1583.

Rodríguez-Castañeda, G., L. A. Dyer, G. Brehm, H. Connahs, R. E. Forkner, and T. R. Walla. 2010. Tropical forests are not flat: how mountains affect herbivore diversity. Ecology Letters 13: 1348-1357.

Ronsted, N., G. Weiblen, W. Clement, N. Zerega, and V. Savolainen. 2008. Reconstructing the phylogeny of figs (Ficus, Moraceae) to reveal the history of the fig pollination mutualism. Symbiosis (Rehovot) 45: 45.

Rossiter, M., J. C. Schultz, and I. T. Baldwin. 1988. Relationships among defoliation, red oak phenolics, and gypsy moth growth and reproduction. Ecology 69: 267-277.

Salminen, J. P., and M. Karonen. 2011. Chemical ecology of tannins and other phenolics: we need a change in approach. Functional Ecology 25: 325-338.

Sam, K., and B. Koane. 2014. New avian records along the elevational gradient of Mt. Wilhelm, Papua New Guinea. Bulletin of the British Ornithologists' Club 134: 116-133.

Sam, K., B. Koane, and V. Novotny. 2015. Herbivore damage increases avian and ant predation of caterpillars on trees along a complete elevational forest gradient in Papua New Guinea. Ecography 38: 293-300.

Sam, K., Koane, B., Bardos, D.C., Jeppy, S. and Novotny, V., 2019. Species richness of birds along a complete rain forest elevational gradient in the tropics: Habitat complexity and food resources matter. Journal of Biogeography 46: 279-290.

Sam, K., B. KoAne, L. SAm, A. Mrazova, S. Segar, M. Volf, M. MoOs, P. SimeK, M.

SISOL, V. NOVOTNY. 2019. Data from: Insect herbivory and herbivores of Ficus species 
along a rainforest elevational gradient in Papua New Guinea. Dryad Digital Repository. doi:10.5061/dryad.kwh70rz06

Sand-Jensen, K., Jacobsen, D. and Duarte, C.M., 1994. Herbivory and resulting plant damage. Oikos: 545-549.

Sanders, N. J., J. P. Lessard, M. C. Fitzpatrick, R. R. J. G. E. Dunn, and Biogeography. 2007. Temperature, but not productivity or geometry, predicts elevational diversity gradients in ants across spatial grains. Global Ecology and Biogeography 16: 640-649.

Scheidel, U., and H. Bruelheide. 2001. Altitudinal differences in herbivory on montane Compositae species. Oecologia 129: 75-86.

Schoonhoven, L. M., J. J. Van Loon, and M. Dicke. 2005. Insect-plant biology. Oxford University Press.

Seldal, T., S. J. Hegland, K. Rydgren, C. Rodriguez-Saona, and J. P. Töpper. 2017. How to induce defense responses in wild plant populations? Using bilberry (Vaccinium myrtillus) as example. Ecology and Evolution 7: 1762-1769.

Strauss, S. Y., J. K. Conner, and S. L. Rush. 1996. Foliar herbivory affects floral characters and plant attractiveness to pollinators: implications for male and female plant fitness. The American Naturalist 147: 1098-1107.

Suzuki, S., K. Kitayama, S.-i. Aiba, M. Takyu, and K. Kikuzawa. 2013. Annual leaf loss caused by folivorous insects in tropical rain forests on Mt. Kinabalu, Borneo. Journal of Forest Research 18: 353-360.

Tvardikova, K. 2013. Trophic relationships between insectivorous birds and insect in Papua New Guinea. PhD Dissertation. University of South Bohemia, Ceske Budejovice. 


\author{
Volf, M., S. T. Segar, S. E. Miller, B. Isua, M. Sisol, G. Aubona, P. Šimek, M. Moos, J. Laitila, \\ and J. J. E. 1. Kim. 2018. Community structure of insect herbivores is driven by \\ conservatism, escalation and divergence of defensive traits in Ficus. Ecology letters 21: 83- \\ 92.
}

Warton, D. I., and F. K. Hui. 2011. The arcsine is asinine: the analysis of proportions in ecology. Ecology 92: 3-10.

Weissflog, A., L. Markesteijn, O. Lewis, L. Comita, and B. Engelbrecht. 2017. Contrasting patterns of insect herbivory and predation pressure across a tropical rainfall gradient. Biotropica 50: 302-311.

Wolda, H. 1987. Altitude, habitat and tropical insect diversity. Biological Journal of the Linnean Society 30: 313-323.

Xiang, H., and J. Chen. 2004. Interspecific variation of plant traits associated with resistance to herbivory among four species of Ficus (Moraceae). Annals of Botany 94: 377-384.

Zava, P. C., and M. V. J. P. e. Cianciaruso. 2014. Can we use plant traits and soil characteristics to predict leaf damage in savanna woody species? Plant ecology 215: 625637.

Zhang, S., Y. Zhang, and K. Ma. 2015. Mutualism with aphids affects the trophic position, abundance of ants and herbivory along an elevational gradient. Ecosphere 6: art253.

Zvereva, E.L., and M.V. Kozlov. 2014. Effects of herbivory on leaf life span in woody plants: a meta-analysis. Journal of ecology 102: 873-881.

Zvereva, E.L., Zverev, V. and M.V., Kozlov.2012. Little strokes fell great oaks: minor but chronic herbivory substantially reduces birch growth. Oikos 121: 2036-2043. 
Figure 1. Location of (a) the study area in Papua New Guinea, and (b) the six study sites of the Mt. Wilhelm elevational gradient in Bismarck Range, Madang Province. An example of the original leaf photos (c) and leaf photos processed in Photoshop, ready to be analysed in ImageJ (d).

Figure 2. Mean ( \pm S.E.) herbivore damage (a; in percentages of individual leaves) and herbivorous arthropod abundances (b) of all species studied at each elevation combined at six study sites along the elevational gradient of Mt. Wilhelm in Papua New Guinea.

Herbivore damage at each elevational site was measured at the end of dry season (Survey 1) and six months later, at the end of the wet season (Survey 2).

Figure 3. Mean $( \pm$ S.E.) herbivore damage (in percentages of individual leaves) of four plant species surveyed at the $200 \mathrm{~m}$ a.s.l. study site (Kausi). ARF $=$ Ficus arfakensis, $\mathrm{CON}=\mathrm{F}$. conocephalifolia, $\mathrm{HAH}=$ F. hahliana, and TRI $=$ F. trichocerasa . Same letters (lowercase letters for Survey A, capital letters for Survey A) mark non-significant results of the Unequal N HSD post-hoc test. ${ }^{* *}$ mark significant difference $(\mathrm{p} \leq 0.01)$ within the species between the two surveys.

Figure 4. Mean ( \pm S.E.) herbivore damage (in percentages of individual leaves) on eight Ficus species surveyed along the Mt. Wilhelm elevational gradient. The values marked with different letters differ significantly from each other (Tukey test, $\mathrm{P}=0.05)$. n.s. $=$ nonsignificant differences in herbivory between elevational study sites for given species. Means are based on the average across the both surveys. 
Figure 5. Scatter plots of trait values for Ficus arfakensis (a) and F. hahliana (b) fitted with second order polynomial curves. For each plant species, following characteristics are fitted: Upper left: trichome density per $10 \mathrm{~mm}^{2}$ (average of both sides of the leaf lamina), upper right: Shannon diversity of triterpenes, lower left: total triterpene content (total sum of peak areas/mg) and lower right: specific leaf area.

Table 1. Characteristics of study sites. Location, elevation and mean annual temperature at six elevational study sites where the research was conducted. The first herbivory measurement was made at the end of the dry season 2014, and the second measurement was made at the end of the rainy season of 2014/2015 (mean monthly precipitation during the study period was $378 \mathrm{~mm}$ ). Mean abundances of herbivorous arthropods (individuals $/ \mathrm{m}^{2}$ ) during both surveys did not differ significantly between the seasons.

\begin{tabular}{|c|c|c|c|c|c|c|c|c|c|}
\hline Locality & Latitude & Longitude & $\begin{array}{l}\text { Elevatio } \\
\mathrm{n}( \pm 50 \mathrm{~m} \\
\text { a.s.l })\end{array}$ & $\begin{array}{l}\text { Temperatu } \\
\text { re }(\text { mean } \\
\left.2014,{ }^{\circ} \mathrm{C}\right)\end{array}$ & $\begin{array}{l}\text { First } \\
\text { survey } \\
\text { (all in } \\
2014)\end{array}$ & $\begin{array}{l}\text { Second } \\
\text { survey (all } \\
\text { in 2015) }\end{array}$ & $\begin{array}{c}\text { Days } \\
\text { betwee } \\
\text { n } \\
\text { survey } \\
\text { s }\end{array}$ & $\begin{array}{l}\text { Herb. } \\
\text { Abund. } \\
\text { First } \\
\text { Survey }\end{array}$ & $\begin{array}{l}\text { Herb. } \\
\text { Abund. } \\
\text { Second } \\
\text { Survey }\end{array}$ \\
\hline Kausi & $05^{\circ} 44^{\prime} 33^{\prime \prime} \mathrm{S}$ & $145^{\circ} 20^{\prime} 01^{\prime \prime} \mathrm{E}$ & 200 & 24.5 & 1-4 Nov & 13-17 Apr & 163 & $3.76 \pm 0.67$ & $5.66 \pm 0.43$ \\
\hline Numba & $05^{\circ} 44^{\prime} 14^{\prime \prime} \mathrm{S}$ & $145^{\circ} 16^{\prime} 12^{\prime \prime} \mathrm{E}$ & 700 & 22.3 & $\begin{array}{c}27-30 \\
\text { Oct }\end{array}$ & 7-9 Apr & 162 & $4.59 \pm 0.42$ & $5.91 \pm 0.52$ \\
\hline Memeku & $05^{\circ} 43^{\prime} 18^{\prime \prime} \mathrm{S}$ & $145^{\circ} 16^{\prime} 17^{\prime \prime} \mathrm{E}$ & 1200 & 19.5 & $\begin{array}{c}21-25 \\
\text { Oct }\end{array}$ & $\begin{array}{c}30 \text { Mar }-4 \\
\text { Apr }\end{array}$ & 160 & $6.03 \pm 0.61$ & $7.25 \pm 0.55$ \\
\hline Bananumbu & $05^{\circ} 45^{\prime} 21^{\prime \prime} \mathrm{S}$ & $145^{\circ} 14^{\prime} 11^{\prime \prime} \mathrm{E}$ & 1700 & 18.4 & $\begin{array}{c}25-28 \\
\text { Oct }\end{array}$ & 8-11 Apr & 165 & $7.05 \pm 0.96$ & $7.49 \pm 0.77$ \\
\hline Sinopass & $05^{\circ} 45^{\prime} 34^{\prime \prime} \mathrm{S}$ & $145^{\circ} 10^{\prime} 49^{\prime \prime} \mathrm{E}$ & 2100 & 15.7 & 6-10 Oct & 14-20 Mar & 159 & $3.83 \pm 0.83$ & $5.02 \pm 0.75$ \\
\hline $\begin{array}{l}\text { Bruno } \\
\text { Sawmill }\end{array}$ & $05^{\circ} 48^{\prime} 57^{\prime \prime} \mathrm{S}$ & $145^{\circ} 09^{\prime} 02^{\prime \prime} \mathrm{E}$ & 2700 & 13.2 & 8-10 Oct & 19-23 Mar & 162 & $3.05 \pm 0.73$ & $4.04 \pm 0.50$ \\
\hline
\end{tabular}


Table 2. Number of saplings (represented by $114 \pm 11.8$ leaves each) of individual species studied at each elevational study site, their overall mean leaf sizes and mean leaf sizes in cases where there were significant differences between leaf sizes at individual elevational study sites. n.s. = non-significant differences in leaf size between elevations.

\begin{tabular}{|c|c|c|c|c|c|c|c|c|}
\hline & 200 & 700 & 1200 & 1700 & 2200 & 2700 & $\begin{array}{l}\text { Mean Leaf } \\
\text { size }\end{array}$ & Leaf sizes dif. \\
\hline Ficus arfakensis & 3 & 3 & & 3 & & & 46.97 & $\begin{array}{c}36.7(67.7 \\
59.6)\end{array}$ \\
\hline Ficus conocephalifolia & 3 & 3 & & & & & 154.10 & n.s. \\
\hline Ficus endochaete & & & 5 & 3 & 3 & 5 & 23.70 & $\begin{array}{c}23.6(31.7) \\
22.3\end{array}$ \\
\hline Ficus hahliana ${ }^{*}$ & 4 & 4 & 5 & 4 & 4 & 5 & 63.76 & n.s. \\
\hline Ficus hombroniana & & & 5 & 4 & 4 & & 34.36 & n.s. \\
\hline Ficus iodotricha & & & & 3 & 3 & 5 & 69.11 & n.s. \\
\hline Ficus saccata & & & & & 3 & 5 & 101.99 & n.s. \\
\hline Ficus trichocerasa $a^{\bullet}$ & 4 & 4 & 5 & 3 & & & 62.33 & n.s. \\
\hline Number of species & 4 & 4 & 4 & 6 & 5 & 4 & & \\
\hline
\end{tabular}


${ }^{*} F$. hahliana is confirmed as a good species from $200-1200 \mathrm{~m}$ of our elevational gradient. After this $(1700 \mathrm{~m}-2700 \mathrm{~m})$ a close relative/sister species occurs. However, this potential split was discussed only recently based on molecular differences. We were not able to distinguish the two species in the time of our experiment. See discussion in Segar et al. in revision.

$\ddagger F$. hombroniana is found between $200-1200 \mathrm{~m}$. There are a few individuals at $1,700 \mathrm{~m}$ but most individuals classified as F. hombroniana here are probably (and at 2,200m) the closely related F. ihuensis.

- F. trichocerasa has two sub-species along the elevational gradient. F. trichocerasa subsp. trichocerasa occurs between 200-1700m and F. trichocerasa subsp. pleioclada occurs between $1700 \mathrm{~m}$ and $2200 \mathrm{~m}$. They co-occur at $1700 \mathrm{~m}$, and both subspecies were included in our study as they are difficult to distinguish in the field at $1700 \mathrm{~m}$. 


\title{
Insect herbivory and herbivores of Ficus species along a
}

\section{rainforest elevational gradient in Papua New Guinea}

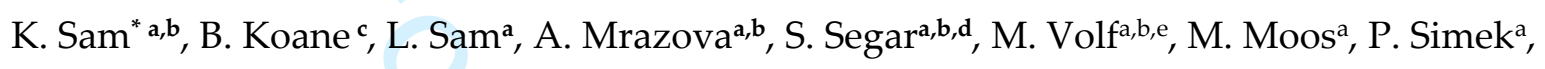 \\ M. Sisolc, V. Novotny ${ }^{\mathrm{a}, \mathrm{b}}$
}

a Biology Centre of Czech Academy of Sciences, Institute of Entomology, Ceske Budejovice, Czech Republic

${ }^{\mathrm{b}}$ Faculty of Science, University of South Bohemia, Ceske Budejovice, Czech Republic

c The New Guinea Binatang Research Center, Madang, Papua New Guinea

${ }^{\mathrm{d}}$ Department of Crop and Environment Sciences, Harper Adams University, UK

e Molecular Interaction Ecology Group, German Centre for Integrative Biodiversity Research (iDiv) Halle-Jena-Leipzig, Leipzig, Germany

* Corresponding author Katerina Sam: katerina.sam.cz@gmail.com 
Table S1. Mean herbivory ( \pm S.D. and S.E.) for all plant species at each of the elevational study site. Results of tests comparing variability between individual saplings within each of the two surveys, and between the two surveys when measurements from all 15,194 leaves. Significant differences are marked in bold. Ficus arfakensis $=$ ARF, Ficus conocephalifolia $=$ $\mathrm{CON}$, Ficus endochaete $=$ END, Ficus hahliana $=$ HAH, Ficus hombroniana $=$ HOM, Ficus iodotricha $=$ IOD, Ficus saccata $=$ SAC, Ficus trichocerasa $=$ TRI.

\begin{tabular}{|c|c|c|c|c|c|c|c|}
\hline & & & & & $\begin{array}{r}\text { Differe } \\
\text { indiv }\end{array}$ & $\begin{array}{l}\text { between } \\
1 \text { trees }\end{array}$ & \\
\hline Species & Site & $\begin{array}{c}\text { Mean } \\
\text { herbivory }\end{array}$ & S.D. & S.E. & Survey 1 & Survey 2 & $\begin{array}{l}\text { Difference between } \\
\text { the two surveys }\end{array}$ \\
\hline ARF & 200 & 1.818 & 4.556 & 0.223 & $<0.001$ & 0.002 & 0.122 \\
\hline ARF & 700 & 2.995 & 6.492 & 0.628 & $<0.001$ & 0.341 & 0.142 \\
\hline ARF & 1700 & 2.139 & 5.245 & 0.437 & 0.406 & 0.415 & 0.211 \\
\hline $\mathrm{CON}$ & 200 & 1.493 & 4.336 & 0.970 & 0.554 & 0.032 & $<0.001$ \\
\hline $\mathrm{CON}$ & 700 & 1.672 & 3.331 & 0.666 & 0.035 & 0.357 & 0.616 \\
\hline END & 1200 & 2.188 & 5.494 & 0.596 & 0.128 & 0.364 & 0.013 \\
\hline END & 1700 & 0.265 & 0.403 & 0.058 & 0.471 & 0.985 & 0.753 \\
\hline END & 2200 & 3.149 & 8.527 & 0.972 & 0.277 & 0.409 & $<0.001$ \\
\hline END & 2700 & 1.522 & 6.150 & 0.446 & 0.496 & 0.207 & 0.002 \\
\hline HAH & 200 & 3.058 & 6.220 & 0.451 & $<0.001$ & $<0.001$ & 0.059 \\
\hline HAH & 700 & 1.370 & 2.349 & 0.266 & 0.316 & 0.143 & 0.805 \\
\hline HAH & 1200 & 1.566 & 5.732 & 0.662 & 0.529 & 0.409 & 0.789 \\
\hline HAH & 1700 & 2.149 & 6.191 & 0.424 & 0.087 & 0.918 & $<0.001$ \\
\hline HAH & 2200 & 1.333 & 3.436 & 0.353 & 0.249 & 0.109 & 0.226 \\
\hline HAH & 2700 & 0.510 & 1.794 & 0.119 & 0.174 & 0.062 & 0.059 \\
\hline HOM & 1200 & 3.091 & 7.509 & 0.219 & $<0.001$ & 0.898 & $<0.001$ \\
\hline $\mathrm{HOM}$ & 1700 & 1.489 & 4.555 & 0.328 & 0.001 & 0.008 & $<0.001$ \\
\hline HOM & 2200 & 1.761 & 6.044 & 0.395 & 0.309 & 0.527 & 0.077 \\
\hline IOD & 1700 & 3.739 & 10.882 & 1.301 & 0.606 & 0.307 & 0.001 \\
\hline IOD & 2200 & 2.489 & 6.816 & 0.501 & 0.017 & 0.319 & 0.014 \\
\hline IOD & 2700 & 1.498 & 4.122 & 0.556 & 0.111 & 0.501 & $<0.001$ \\
\hline SAC & 2200 & 0.725 & 2.264 & 0.281 & 0.069 & 0.095 & $<0.001$ \\
\hline SAC & 2700 & 1.695 & 5.562 & 0.355 & 0.211 & 0.757 & 0.023 \\
\hline TRI & 200 & 2.257 & 5.228 & 0.763 & 0.778 & 0.356 & 0.114 \\
\hline TRI & 700 & 3.277 & 6.466 & 0.611 & $<0.001$ & $<0.001$ & 0.011 \\
\hline TRI & 1200 & 1.505 & 3.109 & 0.440 & 0.064 & 0.319 & 0.319 \\
\hline TRI & 1700 & 2.628 & 4.727 & 0.893 & 0.615 & 0.414 & 0.975 \\
\hline & & & & & & Pr & \\
\hline
\end{tabular}


Table S1. Results of Unequal N HSD post-hoc tests (P values) for herbivore damage among the elevational study sites of the Mt. Wilhelm elevational gradient (see Figure 2). Results for first (_1) and second (_2) survey are presented. Results for herbivory measured in \% under diagonal and results for herbivory measured as actual area damaged in $\mathrm{cm}^{2}$ above diagonal.

\begin{tabular}{|c|c|c|c|c|c|c|c|c|c|c|c|c|}
\hline & 1_200 & 1_700 & 1_1200 & 1_1700 & 1_2200 & 1_2700 & 2_200 & 2_700 & 2_1200 & 2_1700 & 2_2200 & 2_2700 \\
\hline 1_200 & & $<0.001$ & 0.169 & 0.223 & 0.037 & $<0.001$ & 0.993 & $<0.001$ & $<0.001$ & 0.971 & 0.470 & $<0.001$ \\
\hline 1_700 & $<0.001$ & & $<0.001$ & $<0.001$ & $<0.001$ & $<0.001$ & 0.013 & 0.971 & $<0.001$ & $<0.001$ & $<0.001$ & $<0.001$ \\
\hline 1_1200 & 0.169 & $<0.001$ & & 0.466 & $<0.001$ & $<0.001$ & 0.013 & 1.000 & $<0.001$ & 0.235 & 0.235 & $<0.001$ \\
\hline 1_1700 & 0.223 & $<0.001$ & 0.169 & & $<0.001$ & $<0.001$ & 0.969 & 0.003 & 0.002 & 0.986 & 0.391 & $<0.001$ \\
\hline 1_2200 & 0.037 & $<0.001$ & $<0.001$ & $<0.001$ & & 0.466 & 0.019 & 0.007 & 0.021 & $<0.001$ & 0.005 & 0.516 \\
\hline 1_2700 & $<0.001$ & $<0.001$ & $<0.001$ & $<0.001$ & 0.466 & & $<0.001$ & $<0.001$ & $<0.001$ & $<0.001$ & 0.953 & $<0.001$ \\
\hline 2_200 & 0.993 & $<0.001$ & 0.466 & 0.969 & 0.019 & 0.013 & & $<0.001$ & $<0.001$ & 0.470 & 0.696 & $<0.001$ \\
\hline 2_700 & $<0.001$ & 0.986 & $<0.001$ & 0.003 & 0.007 & $<0.001$ & $<0.001$ & & 1.000 & 0.007 & 0.007 & $<0.001$ \\
\hline 2_1200 & $<0.001$ & $<0.001$ & $<0.001$ & 0.002 & 0.021 & $<0.001$ & $<0.001$ & 1.000 & & 0.021 & $<0.001$ & $<0.001$ \\
\hline 2_1700 & 0.971 & $<0.001$ & 0.235 & 0.891 & 0.007 & $<0.001$ & 0.470 & 0.007 & 0.021 & & 0.989 & $<0.001$ \\
\hline 2_2200 & 0.470 & $<0.001$ & 0.235 & 0.470 & 0.005 & 0.470 & 0.696 & 0.007 & $<0.001$ & 0.989 & & $<0.001$ \\
\hline 2_2700 & $<0.001$ & $<0.001$ & $<0.001$ & $<0.001$ & 0.516 & $<0.001$ & $<0.001$ & $<0.001$ & $<0.001$ & $<0.001$ & $<0.001$ & \\
\hline
\end{tabular}


Figure S1. Mean ( \pm S.E.) herbivory damage in percentages of leaf area (a) and in $\mathrm{cm}^{2}$ of leaf area (b) of all species studied at each elevation combined at six study sites along the elevational gradient of Mt. Wilhelm in Papua New Guinea. Herbivore damage at each elevational site was measured at the end of dry season (Survey 1) and six months later, at the end of the wet season (Survey 2). Species surveyed at 3200 and $3700 \mathrm{~m}$ a.s.l. were Macaranga melanosticta, Myrsine papuana, Myrsine womersleyi, Pittosporum berberidoides. The data on higher elevations are not published yet, but we collected them the exact same way as we collected the Ficus species in current study.
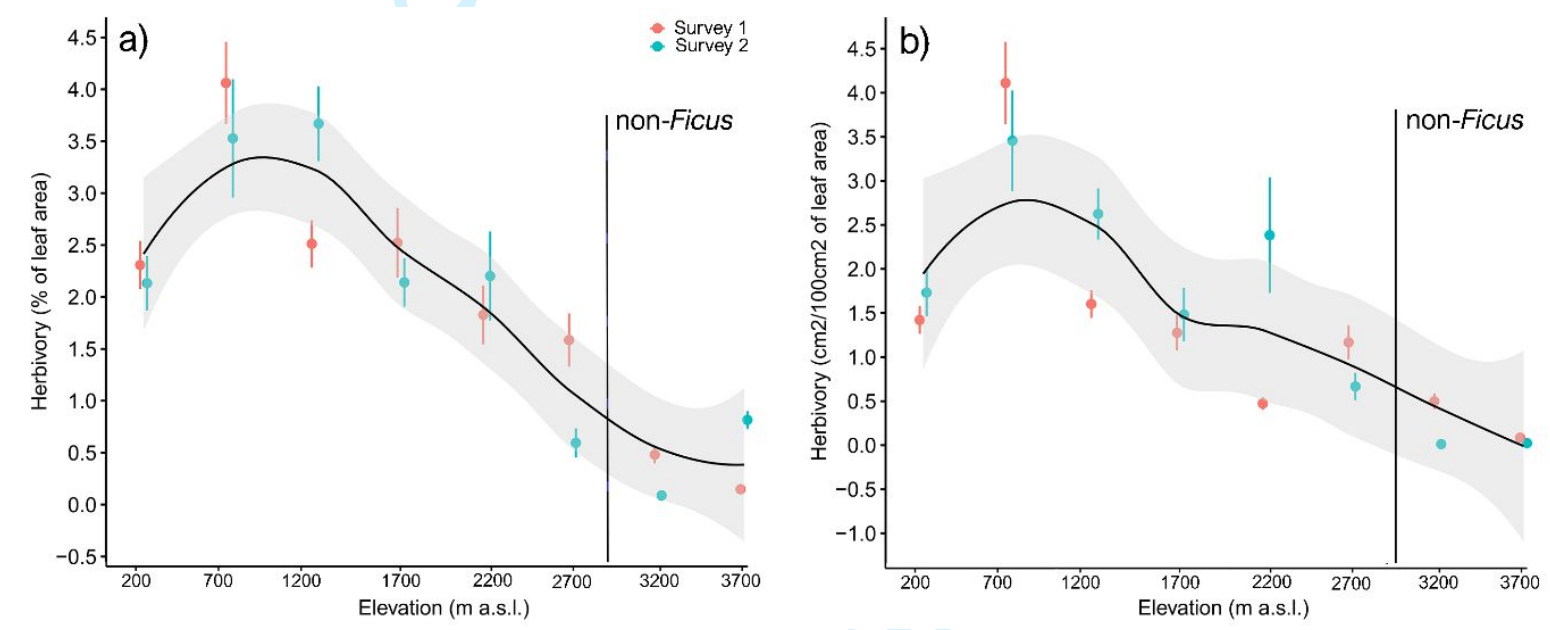
Table S2. Correlations between plant defences and herbivory of two plant species

\begin{tabular}{|l|c|c|c|c|}
\hline & \multicolumn{2}{|c|}{ F. arfakensis } & \multicolumn{2}{c|}{ F. hahliana } \\
\hline & $\mathrm{r}$ & $\mathrm{p}$ & $\mathrm{r}$ & $\mathrm{p}$ \\
\hline Triterpene content & 0.02 & 0.98 & 0.73 & $\mathbf{0 . 0 5}$ \\
\hline Triterpene diversity & -0.74 & $\mathbf{0 . 0 5}$ & -0.77 & $\mathbf{0 . 0 4}$ \\
\hline C:N ratio & 0.68 & 0.52 & -0.6 & 0.13 \\
\hline Trichome density & 0.99 & $\mathbf{0 . 0 4}$ & -0.87 & $\mathbf{0 . 0 2}$ \\
\hline Trichome length & 0.18 & 0.88 & 0.2 & 0.72 \\
\hline SLA & -0.06 & 0.82 & 0.33 & 0.72 \\
\hline Insect abundance & 0.96 & 0.16 & -0.27 & 0.44 \\
\hline
\end{tabular}

\section{Methods S1}

\section{Physical Traits}

We measured trichome density and specific leaf area (SLA), a surrogate for leaf thickness and toughness, which is also frequently correlated with water content (Groom \& Lamont 1999), as parameters of leaf morphology with a possible impact on leaf-chewing insects. The physical traits were measured using leaf discs. Leaf discs were cut (avoiding the central vein) and air dried to constant weight. The total number of trichomes per $10 \mathrm{~mm}^{2}$ and their average length was measured on five leaf discs per individual using ImageJ (ver.1.48). Values for dorsal and ventral sides of the discs were combined. Specific leaf area (SLA) was calculated as the area per unit mass of five dried leaf disc of known diameter for each individual.

\section{Terpenoids}

Chemicals: Deionized water (NANOpure Barnstead water purification system, Watrex, Prague, Czech Republic), LC/MS-grade methanol and 2-propanol, Fisher Scientific (Pardubice, Czech Republic), formic acid (Sigma-Aldrich, Prague, Czech Republic) were used.

Sample preparation: Approximately $50 \mathrm{mg}$ of dried powdered sample was ground with $1 \mathrm{ml}$ methanol in a TissueLyser LT (Dynex Technologies, Bustehrad, Czech Republic) at $30 \mathrm{~Hz}$ for $2 \mathrm{~min}$. After centrifugation ( $10000 \mathrm{rpm}$ ) at $8^{\circ} \mathrm{C}$ for $10 \mathrm{~min}$, a $100 \mu \mathrm{l}$ of the supernatant's aliquot was mixed with $200 \mu 1$ of methanol containing $0.1 \%$ formic acid.

HPLC-HRMS equipment: Triterpenes were measured on a Dionex Ultimate 3000 LC system equipped with an Open XRS autosampler and coupled to a Q Exactive Plus Orbitrap mass spectrometer (Thermo Fisher Scientific, San Jose, CA, USA). A reversed phase Kinetex C18 100AHPLC column, 150mm x $2.1 \mathrm{~mm}$ i.d., 2.6 $\mu \mathrm{m}$ (Phenomenex, Torrance, CA, USA) was used for separation of analytes. A positive atmospheric pressure ionization mode (APCI) 
and a combined full scan mass range $(250-625 \mathrm{Da})$ and a data dependent tandem $\mathrm{MS}^{2}$ scan modes were used. Acquired data were processed by an Xcalibur 2.1 Software (Thermo Fisher Scientific) and the triterpene data were further mined by means of an in-house developed Metabolite Mapper platform.

HPLC-HRMS analysis (Liquid chromatography - high resolution mass spectrometry)

Analytical conditions: Flow rate, $200 \mu \mathrm{L} / \mathrm{min}$; injection volume of $5 \mu \mathrm{L}$; mobile phase, $\mathrm{A}=$ $0.1 \%$ formic acid in 2-propanol, $\mathrm{B}=0.1 \%$ formic acid in $1 \% 2$-propanol and methanol, $\mathrm{C}=$ $0.1 \%$ formic acid in water. Gradient elution,

0 min, $0 \% \mathrm{~A}+85 \% \mathrm{~B}+15 \% \mathrm{C} ; 12.0 \mathrm{~min}, 29 \% \mathrm{~A}+70 \% \mathrm{~B}+1 \% \mathrm{C} ; 18.5 \mathrm{~min}, 29 \% \mathrm{~A}+$ $70 \% \mathrm{~B}+1 \% \mathrm{C} ; 19.0 \mathrm{~min}, 0 \% \mathrm{~A}+85 \% \mathrm{~B}+18 \% \mathrm{C} ; 25.0 \mathrm{~min}, 0 \% \mathrm{~A}+85 \% \mathrm{~B}+15 \%$; total analysis time, $30 \mathrm{~min}$.

HRMS analytical conditions: Full HRMS scanning: resolving power, 70 000; scan rate, $\pm 3 \mathrm{~Hz}$; automatic gain control (AGC) target, $3 \times 10^{6}$; maximum ion injection time (IT), $100 \mathrm{~ms}$. The data dependent $\mathrm{MS}^{2}$ scanning: resolving power, 17 500; automatic gain control (AGC) target, $2 \times 10^{5}$; maximum ion injection time (IT), $100 \mathrm{~ms}$; isolation window; $3 \mathrm{Da}$, and normalized collision energy, 32 , TopN 1. Ion source: spray voltage, $3.0 \mathrm{kV}$; capillary temperature, $250^{\circ} \mathrm{C}$; sheath gas, $25 \mathrm{au}$; aux gas, $5 \mathrm{au}$; auxiliary gas, 1 au; auxiliary gas heater temperature, $250^{\circ} \mathrm{C}$; S-Lense, $60 \mathrm{au}$; lock mass, hexakis(2,2-difluoroethoxy)phosphazene, 621.0211 Da.

Data Proccesing: A list of presumed terpenoid metabolites was compiled reviewing literature, Table S1. For data processing, only metabolites that were detected in at least $50 \%$ of the sample pool were used for statistical processing.

A list of the presumed terpenoid metabolites involved in this study:

Compound name
Stigmasterol
Lupeol
8,26 -cyclo-urs-21-en-3 $\beta, 20 \beta$-diol (ursane type)
$3 \beta$-acetoxy-8,26-cyclo-ursan-20 $\beta$-ol
3-friedelanone
Oleanolic acid
betulinic acid
lupeol acetate
$\alpha$ - and $\beta$-amyrine
3,5,7,4-tetrahydroxyflavane
3,5,7,3,4-pentahydroxyflavane

Composition $[\mathbf{M}+\mathbf{H}]^{+}$

$\mathrm{C}_{29} \mathrm{H}_{48} \mathrm{O} \quad \mathbf{4 1 3 . 3 7 7 8}$

$\mathrm{C}_{30} \mathrm{H}_{50} \mathrm{O}$

$\mathrm{C}_{30} \mathrm{H}_{49} \mathrm{O}_{2}$

$\mathrm{C}_{32} \mathrm{H}_{52} \mathrm{O}_{3}$

$\mathrm{C}_{30} \mathrm{H}_{50} \mathrm{O}$

$\mathrm{C}_{30} \mathrm{H}_{48} \mathrm{O}_{3}$

$\mathrm{C}_{30} \mathrm{H}_{48} \mathrm{O}_{3}$

$\mathrm{C}_{32} \mathrm{H}_{52} \mathrm{O}_{2}$

$\mathrm{C}_{30} \mathrm{H}_{50} \mathrm{O}$

$\mathrm{C}_{15} \mathrm{H}_{14} \mathrm{O}_{5}$

$\mathrm{C}_{15} \mathrm{H}_{14} \mathrm{O}_{6}$

$\mathrm{C}_{29} \mathrm{H}_{48} \mathrm{O}_{2}$

$\mathrm{C}_{27} \mathrm{H}_{42} \mathrm{O}_{2}$
427.3935

275.0914

291.0863

429.3727

399.3258
[M-

$\left.\mathrm{H}_{2} \mathrm{O}+\mathrm{H}\right]^{+}$

395.3672

409.3829

424.3700

467.3883

409.3829

439.3570

439.3570

451.3934

409.3829

257.0808

273.0757

411.3621

381.3152 
$3 b$-acetoxy-15a-hydroxy-13,27-cyclours-11-ene

$\mathrm{C}_{32} \mathrm{H}_{50} \mathrm{O}$

483.3833

465.3727

3b-acetoxy-12a-formyloxy-13,27-cycloursan-11a-ol

$\mathrm{C}_{33} \mathrm{H}_{52} \mathrm{O}_{5}$

529.3888

511.3782

3b-acetoxy-12,19-dioxo-13(18)-oleanene

$\mathrm{C}_{32} \mathrm{H}_{48} \mathrm{O}_{4}$

497.3626

479.3520

3b-acetoxy-19(29)-taraxasten-20a-ol

$\mathrm{C}_{32} \mathrm{H}_{52} \mathrm{O}_{3}$

485.3989

467.3883

3b-acetoxy-21a,22a-epoxytaraxastan-20a-ol

$\mathrm{C}_{32} \mathrm{H}_{52} \mathrm{O}_{4}$

501.3939

483.3833

3,22-dioxo-20-taraxastene

$\mathrm{C}_{30} \mathrm{H}_{46} \mathrm{O}_{2}$

439.3571

421.3465

3b-acetoxy-11a,12a-epoxy-16-oxo-14-taraxerene

$\mathrm{C}_{32} \mathrm{H}_{48} \mathrm{O}_{4}$

497.3626

479.3520

3b-acetoxy-25-methoxylanosta-8,23-diene

$\mathrm{C}_{33} \mathrm{H}_{54} \mathrm{O}_{3}$

499.4146

481.4040

oleanolic acid

$\mathrm{C}_{30} \mathrm{H}_{48} \mathrm{O}_{3}$

457.3676

439.3570

acetylbetulinic acid

$\mathrm{C}_{32} \mathrm{H}_{50} \mathrm{O}_{4}$

499.3782

481.3676

betulonic acid

$\mathrm{C}_{30} \mathrm{H}_{46} \mathrm{O}_{3}$

545.3520

527.3414

acetylursolic acid

$\mathrm{C}_{32} \mathrm{H}_{50} \mathrm{O}_{4}$

499.3782

481.3676

ursonic acid

$\mathrm{C}_{30} \mathrm{H}_{46} \mathrm{O}_{3}$

455.3520

437.3414

ursolic acid

$\mathrm{C}_{30} \mathrm{H}_{48} \mathrm{O}_{3}$

457.3676

439.3570

3-oxofriedelan-28-oic acid

$\mathrm{C}_{30} \mathrm{H}_{48} \mathrm{O}_{3}$

457.3676

439.3570

acetate-a-amyrin

$\mathrm{C}_{32} \mathrm{H}_{52} \mathrm{O}_{2}$

469.4040

451.3934

acetate-b-amyrin

3 b -acetoxy-22,23,24,25,26,27-hexanordammaran-20-one

$\mathrm{C}_{32} \mathrm{H}_{52} \mathrm{O}_{2}$

469.4040

451.3934

3 b -acetoxy-20,21,22,23,24,25,26,27-octanordammaran-17b -ol

$\mathrm{C}_{26} \mathrm{H}_{42} \mathrm{O}_{3}$

403.3207

385.3101

$3 \mathrm{~b}$-acetoxy-(20R,22E,24RS)-20,24-dimethoxydammaran-22-en-25-ol

$\mathrm{C}_{24} \mathrm{H}_{40} \mathrm{O}_{3}$

377.3050

359.2944

$\mathrm{C}_{34} \mathrm{H}_{58} \mathrm{O}_{5}$

$\mathbf{5 4 7 . 4 3 5 7}$

529.4251

$3 \mathrm{~b}$-acetoxy-(20S,22E,24RS)-20,24-dimethoxydammaran-22-en-25-ol

$\mathrm{C}_{34} \mathrm{H}_{58} \mathrm{O}_{5}$

547.4357

529.4251

29(20-19)abeolupane-3,20-dione

$\mathrm{C}_{30} \mathrm{H}_{48} \mathrm{O}_{2}$

441.3727

423.3621

19,20-secoursane-3,19,20-trione

$\mathrm{C}_{30} \mathrm{H}_{48} \mathrm{O}_{3}$

457.3676

439.3570

lupenone

$\mathrm{C}_{30} \mathrm{H}_{48} \mathrm{O}$

425.3778

407.3672

a-amyrone

$\mathrm{C}_{30} \mathrm{H}_{48} \mathrm{O}$

425.3778

407.3672

20(30)-taraxastene-3b ,21a-diol

$\mathrm{C}_{30} \mathrm{H}_{50} \mathrm{O}_{2}$

443.3884

425.3778

20a,21a-epoxytaraxastan-3b -ol

$\mathrm{C}_{30} \mathrm{H}_{50} \mathrm{O}_{2}$

443.3884

425.3778

20-taraxastene-3b ,22b -diol

$\mathrm{C}_{30} \mathrm{H}_{50} \mathrm{O}_{2}$

443.3884

425.3778

and $3 b$-acetoxy-20-taraxasten-22-

$\mathrm{C}_{32} \mathrm{H}_{50} \mathrm{O}_{3}$

483.3833

465.3727

20-taraxasten-3b -ol (pseudo-Taraxasterol)

$\mathrm{C}_{30} \mathrm{H}_{50} \mathrm{O}$

427.3935

409.3829

$3 \mathrm{~b}$-acetoxy-11a-methoxy-12-ursene

$\mathrm{C}_{33} \mathrm{H}_{54} \mathrm{O}_{3}$

499.4146

481.4040

$3 b$-acetoxy-11a-ethoxy-12-ursene

$\mathrm{C}_{34} \mathrm{H}_{56} \mathrm{O}_{3}$

513.4302

495.4196

$3 b$-acetoxy-11a-hydroperoxy-12-ursene

$\mathrm{C}_{32} \mathrm{H}_{52} \mathrm{O}_{4}$

501.3939

483.3833

3b -hydroxy-11a-hydroperoxy-12-ursene

$\mathrm{C}_{30} \mathrm{H}_{50} \mathrm{O}_{3}$

459.3833

441.3727

$3 \mathrm{~b}$-acetoxy-11a-ethoxy-12-oleanene

$\mathrm{C}_{34} \mathrm{H}_{56} \mathrm{O}_{3}$

513.4302

495.4196

$3 \mathrm{~b}$-acetoxy-11a-hydroperoxy-12-oleanene

$\mathrm{C}_{32} \mathrm{H}_{52} \mathrm{O}_{4}$

$\mathbf{5 0 1 . 3 9 3 3}$

483.3827 


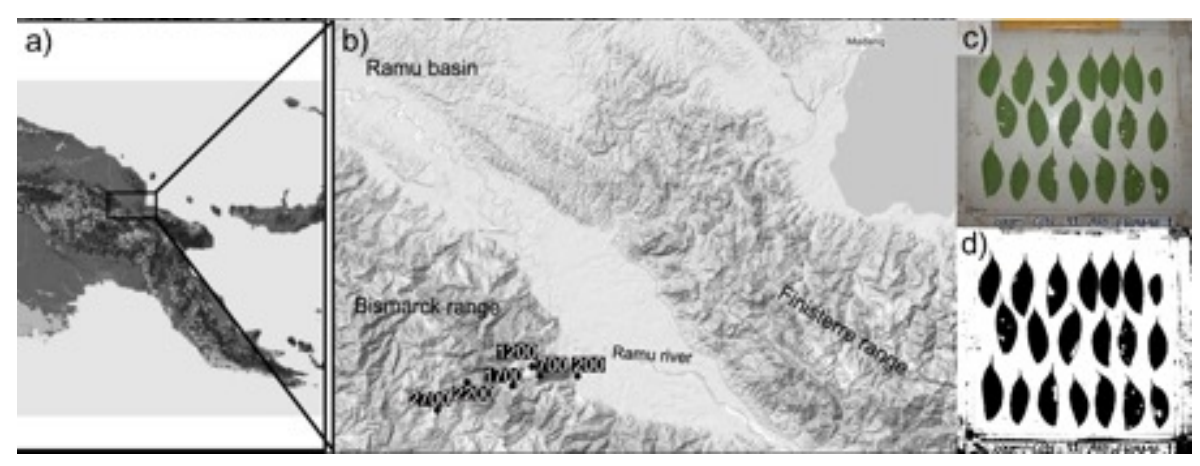

$159 \times 58 \mathrm{~mm}(72 \times 72 \mathrm{DPI})$ 

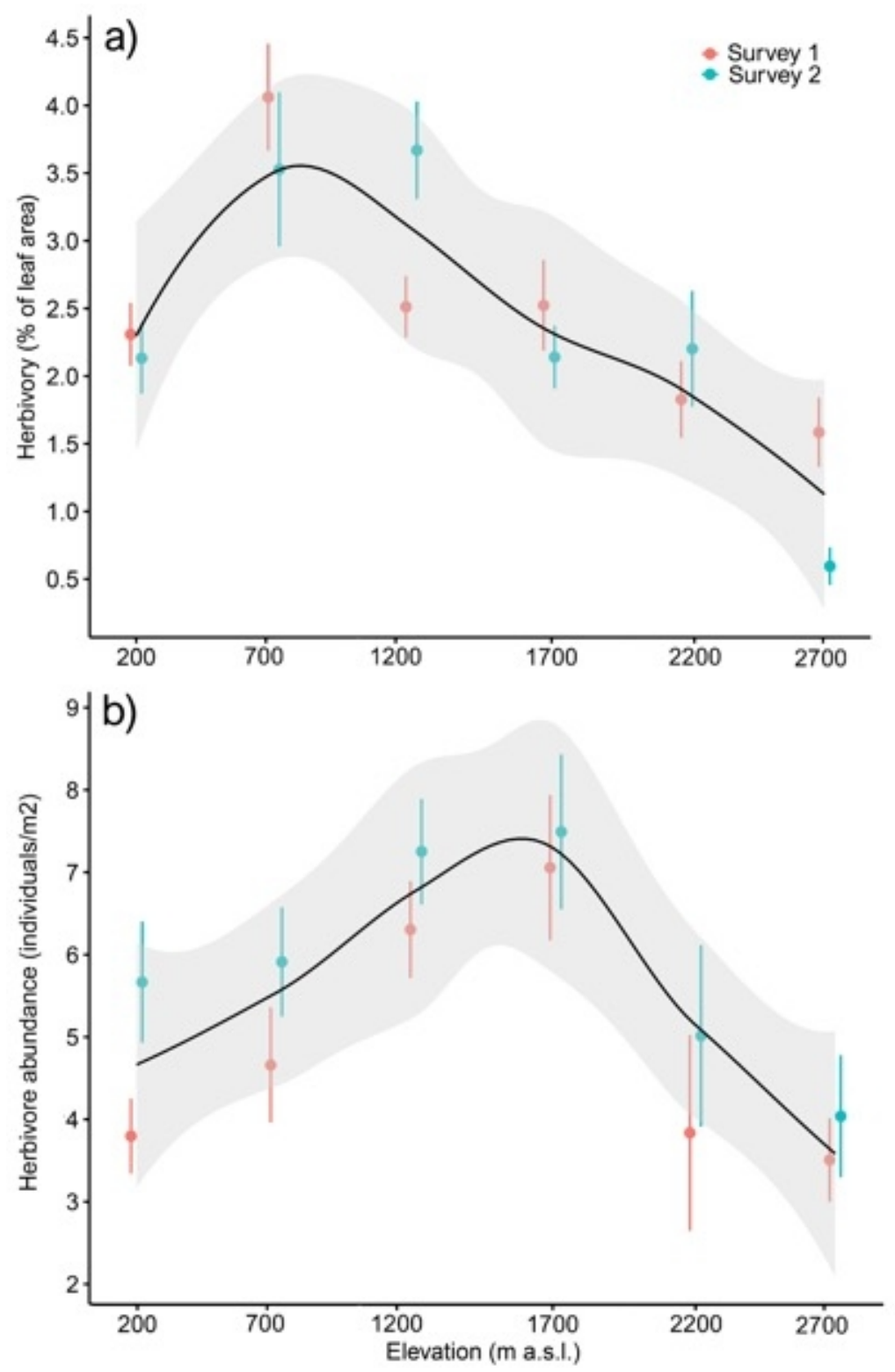

$145 \times 221 \mathrm{~mm}(72 \times 72 \mathrm{DPI})$ 


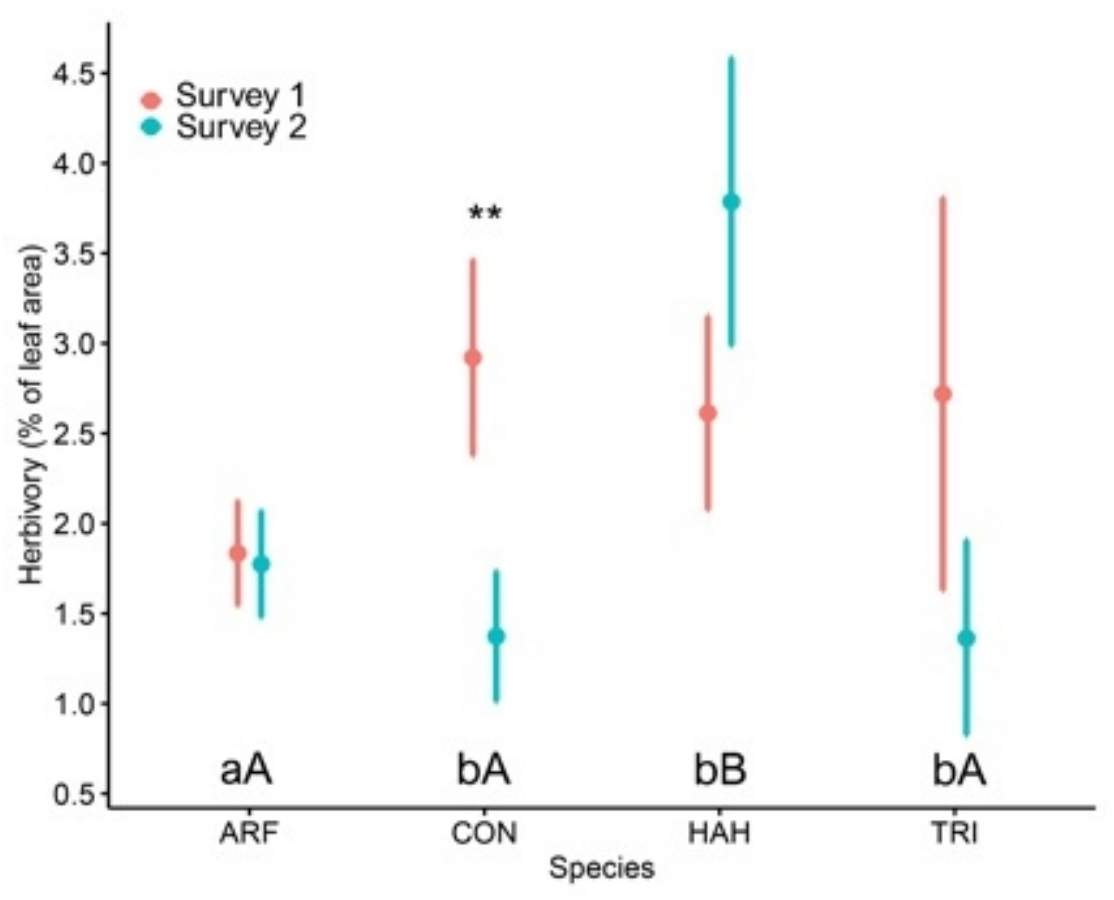

$158 \times 120 \mathrm{~mm}(72 \times 72$ DPI $)$ 

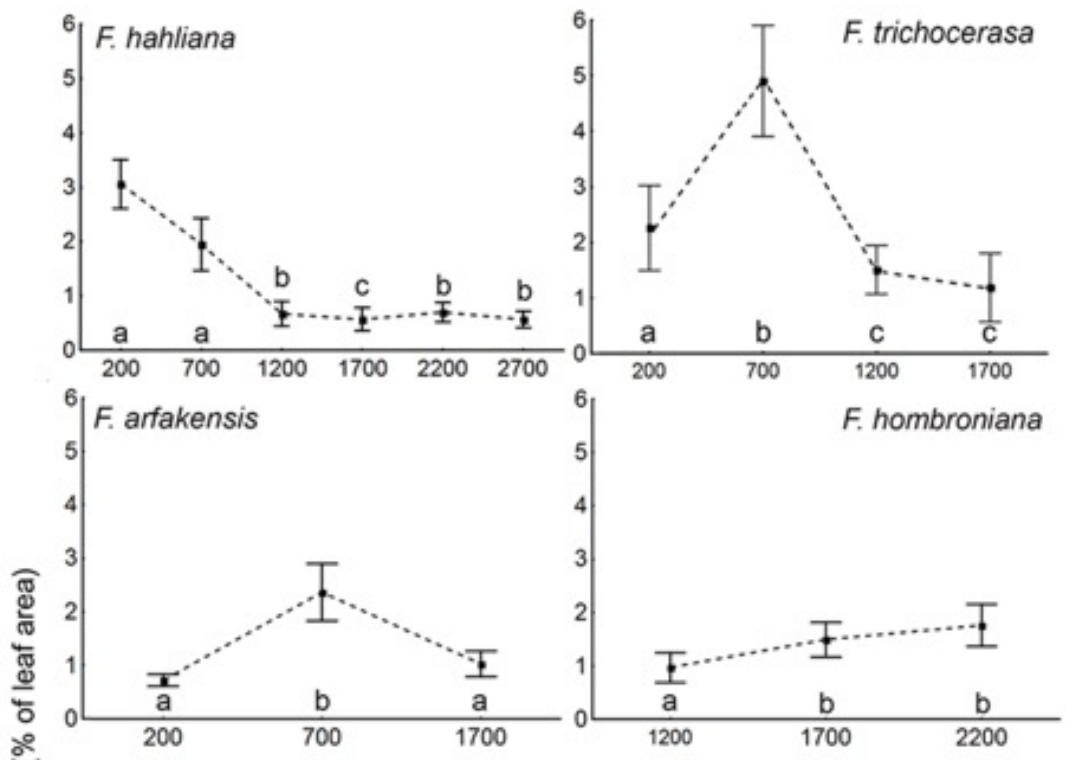
a)

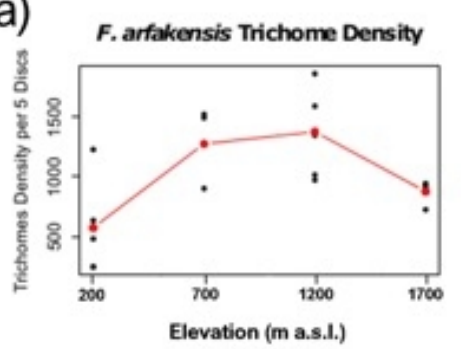

Elevation (m a.s.l.)

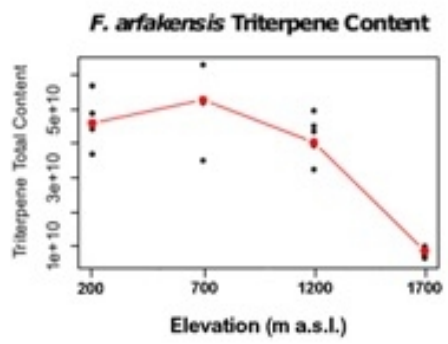

b)
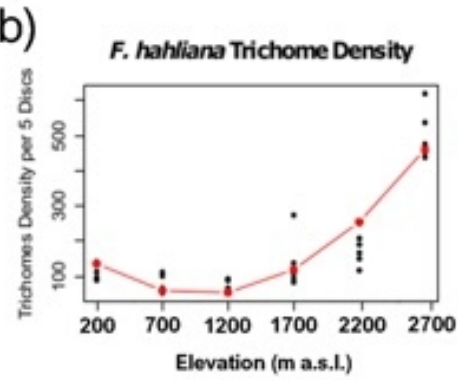

F. hahliana Triterpene Content

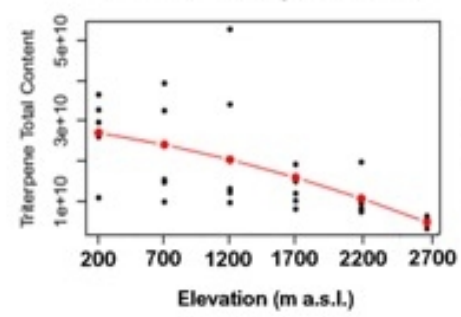

F. arfakensis Triterpene Diversity

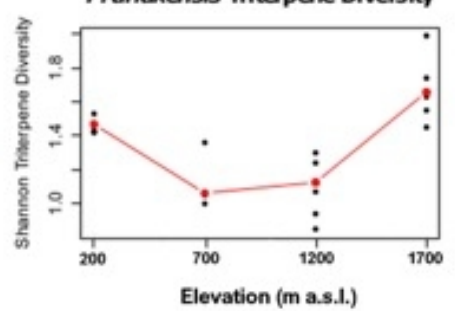

F. arfakensis Specific Leaf Area

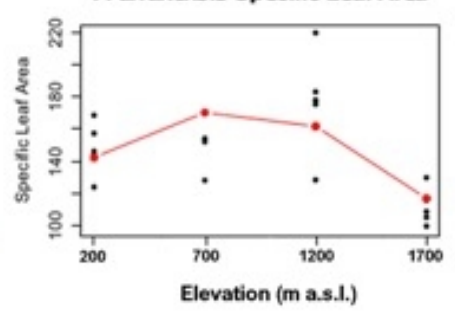

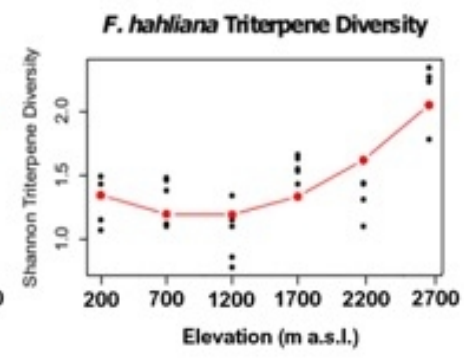

$146 \times 233 \mathrm{~mm}(72 \times 72$ DPI $)$ 


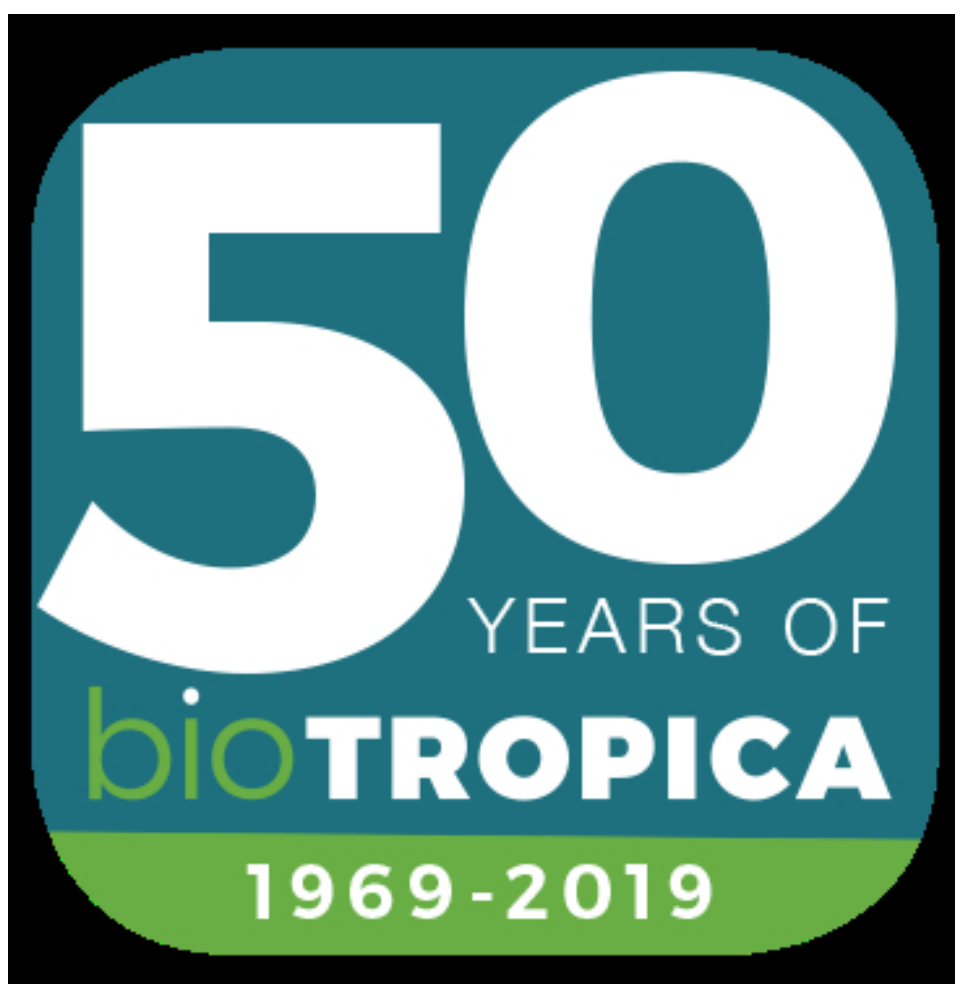

30

31

32

33

34

35

36

37

38

39

40

41

42

43

44

45

46

47

48

49

50

51

52

53

54

55

56

57

58

59 